\title{
Role of biology in the air-sea carbon flux in the Bay of Bengal and Arabian Sea
}

\author{
M K Sharada*, P S Swathi, K S Yajnik and C Kalyani Devasena \\ CSIR Centre for Mathematical Modelling and Computer Simulation (C-MMACS), \\ Wind Tunnel Road, Bangalore 560 037, India. \\ *e-mail: sharada@cmmacs.ernet.in
}

\begin{abstract}
A physical-biological-chemical model $(\mathrm{PBCM})$ is used for investigating the seasonal cycle of air-sea carbon flux and for assessing the effect of the biological processes on seasonal time scale in the Arabian Sea (AS) and Bay of Bengal (BoB), where the surface waters are subjected to contrasting physical conditions. The formulation of PBCM is given in Swathi et al (2000), and evaluation of several ammonium-inhibited nitrate uptake models is given in Sharada et al (2005). The PBCM is here first evaluated against JGOFS data on surface $\mathrm{pCO}_{2}$ in AS, Bay of Bengal Process Studies (BoBPS) data on column integrated primary productivity in BoB, and WOCE I1 data on dissolved inorganic carbon (DIC) and alkalinity (ALK) in the upper 500 meters at $9^{\circ} \mathrm{N}$ in $\mathrm{AS}$ and at $10^{\circ} \mathrm{N}$ in $\mathrm{BoB}$ in September-October. There is good qualitative agreement with local quantitative discrepancies.

The net effect of biological processes on air-sea carbon flux on seasonal time scale is determined with an auxiliary computational experiment, called the abiotic run, in which the biological processes are turned off. The difference between the biotic run and abiotic run is interpreted as the net effect of biological processes on the seasonal variability of chemical variables. The net biological effect on air-sea carbon flux is found to be highest in southwest monsoon season in the northwest AS, where strong upwelling drives intense new production. The biological effect is larger in AS than in $\mathrm{BoB}$, as seasonal upwelling and mixing are strong in AS, especially in the northeast, while coastal upwelling and mixing are weak in BoB.
\end{abstract}

\section{Introduction}

Intensification of scientific interest in the role of oceans in climate change issues has led to JGOFS, WOCE and other observational programmes, including Bay of Bengal Process Studies (BoBPS; Prasanna Kumar et al 2002, 2004; Madhupratap et al 2003), in the north Indian Ocean since the mid-nineties. Subsequently, a variety of biogeochemical issues have been investigated with dynamical models to understand the underlying processes using the available data (see Wiggert et al 2005 for a lucid review). Statistical models (e.g., Sabine et al 2000; Sarma 2003; Sarma et al 2003; Bates et al 2006a, 2006b) have also been used to extrapolate the cruise data to infer the seasonal variability of air-sea carbon flux in the tropical and subtropical Indian Ocean.

The Indian peninsula and the island of Sri Lanka, in effect, partition the north Indian Ocean into eastern and western sub-basins which can exchange mass, momentum, energy and tracers only through $0^{\circ} \mathrm{N}-\sim 6^{\circ} \mathrm{N}$ south of Sri Lanka and to a smaller extent through a narrow shallow channel north of Sri Lanka. The eastern and western sub-basins are thus weakly coupled. A seasonal positive-feedback control system maintains a higher SST and supports larger deep convection in the atmosphere over the $\mathrm{BoB}$ with precipitation exceeding evaporation, and strengthening

Keywords. Carbon flux; Bay of Bengal; Arabian Sea; biotic; abiotic; coupled model. 
the stratification in the ocean as explained with heat budget analysis by Shenoi et al (2005). The resulting zonal chemical contrast was highlighted by Goyet et al (1999) by analyzing dissolved inorganic carbon (DIC) and alkalinity (ALK) in vertical sections along nominally $9 / 10^{\circ} \mathrm{N}$ in WOCE I1 data (29 August-16 October 1995). Indeed, they pointed out that the difference between the highest DIC in surface waters in the AS and the lowest in $\mathrm{BoB}$ was much larger than in other oceans over comparable distances. Our object here is to investigate the seasonal variability of the airsea carbon flux in the north Indian Ocean keeping in view the underlying physical contrast and biological processes.

Sarmiento et al (2000) investigated the global effect of combined terrestrial and oceanic sources on the basis of three ocean carbon cycle models. They examined the processes determining the magnitude of the pre-industrial interhemispheric flux of carbon in the three ocean carbon models. The sea-air flux obtained from the combined model (which includes solubility as well as the biological pump) showed substantial cancellation of solubility model fluxes by the biological pump fluxes. The biological pump flux was of opposite sign to that of solubility model almost everywhere except in the tropics. Consequently, the combined model flux was relatively small everywhere except in the tropics.

Blackford and Burkill (2002) have studied the carbon cycling in AS using a one-dimensional vertical hydrodynamic model coupled to a complex ecosystem model by simulating the annual cycle at three contrasting stations. Their study indicated that physically driven outgassing of $\mathrm{CO}_{2}$ predominated in monsoonal upwelling systems but ecological activity might significantly moderate $\mathrm{CO}_{2}$ outgassing in the AS interior. However, they did not use a complete chemical model to determine all the components of the carbon system. Nitrogen fluxes determined from their ecosystem model were simply multiplied by a constant Redfield ratio to yield carbon fluxes.

Several larger issues of modelling and methodology have to be addressed in order to assure reliability of the simulations. They include judicious choices in modelling not only of marine ecosystem and marine carbon chemistry but also of physical forcing. The strategy we have adopted is to use relatively mature and well-tested models of physical oceanography, marine ecosystem and carbon chemistry, but only as basic prototypes. Attention is paid to the modifications necessitated by subsequent observations and to the determination of certain ecosystem parameters using extensive comparisons with a variety of biological and chemical data from satellites, ships and buoys.
Salient features of physical, biological and chemical model components are explained in section 2 . Thereafter, we discuss in section 3 the simulation experiments undertaken by us and the underlying reasoning of the parametric sensitivity analysis, which resulted in the selection of a particular set of parameters and the corresponding simulation and its results for further discussion in section 4 . In order to isolate the chemical effect of biological processes from the physical processes, we compare in section 5 the air-sea carbon efflux in the selected simulation with an abiotic simulation (a coupled physical-chemical simulation). Finally, section 6 gives our major conclusions on the basis of the comparative study of coupled model simulations.

\section{Modelling methodology}

The present physical-biological-chemical model (PBCM) is designed to investigate the seasonal carbon cycle in the north Indian Ocean where forcing by reversing monsoonal winds is the dominant factor determining circulation in the upper ocean. Our strategy is to integrate three well-developed models, namely, the Modular Ocean Model (MOM, Pacanowski 1995), the ecosystem model of Fasham et al (1990) and marine carbon chemistry model of Peng et al (1987) and Drange (1994). The following sections describe how the three models have been adapted and integrated for the present requirements.

\subsection{Physical model}

The physical model (PM) is an OGCM having 35 levels and 10-meter vertical resolution in the euphotic layer (Swathi et al 2000, with refinements given in Sharada et al 2005; see table 1). Since the model formulation of PM is discussed at length in these papers, it is sufficient to summarize the salient features of PM.

The Pacanowski-Philander formulation (Pacanowski and Philander 1981) models mixed layer turbulence driven by strong monsoonal winds and winter cooling in the AS and also suppression by seasonal stratification in the $\mathrm{BoB}$. The southern boundary is chosen at $15^{\circ} \mathrm{S}$ as our focus is on the north Indian Ocean. The sponge boundary condition is implemented by relaxing the model temperature and salinity in $5^{\circ} \mathrm{S}-15^{\circ} \mathrm{S}$ to climatology (Levitus et al 1994) on a time scale of 30 days. The PM has 10-meter resolution in the upper 120 meters to enable capturing stratification effects in the upper ocean especially in the BoB and the penetration of solar radiation. The MOM 2.2 model with rigid lid condition at the upper surface is forced by COADS monthly winds. Since sparse 
Table 1. Salient features of the physical model.

\begin{tabular}{|c|c|c|}
\hline Physical model & & MOM 2.2 \\
\hline Computational domain & & $15^{\circ} \mathrm{S}-27^{\circ} \mathrm{N} ; 37.6^{\circ} \mathrm{E}-100.4^{\circ} \mathrm{E}$ \\
\hline Resolution & $\begin{array}{l}\text { Latitude } \\
\text { Longitude } \\
\text { Vertical }\end{array}$ & $\begin{array}{l}\text { Varying from } 1^{\circ} \text { at } 15^{\circ} \mathrm{S} \text { to } 0.4^{\circ} \text { above } 0^{\circ} \mathrm{N} \\
0.4^{\circ} \\
35 \text { levels, } 12 \text { in upper } 120 \text { meters }\end{array}$ \\
\hline Bottom topography & & Scripps $1^{\circ}$ \\
\hline Boundary conditions & South & $\begin{array}{l}\text { Closed; no Indonesian through flow. Effects of } \\
\text { river and groundwater discharge are modelled } \\
\text { indirectly by restoring } \\
\text { Closed; temperature and salinity restored in } \\
15^{\circ} \mathrm{S}-5^{\circ} \mathrm{S} \text { to interpolated Levitus values (time } \\
\text { scale: } 30 \text { days) }\end{array}$ \\
\hline Surface forcing & $\begin{array}{l}\text { Wind stress } \\
\text { Fluxes } \\
\text { Restoring time }\end{array}$ & $\begin{array}{l}\text { COADS monthly } \\
\text { Heat and salt fluxes from a 50-year climatological } \\
\text { run. Short wave fluxes from Oberhuber (1988). } \\
\text { Precipitation is modelled indirectly } \\
30 \text { days for temperature and salinity }\end{array}$ \\
\hline Parameterization & $\begin{array}{l}\text { Horizontal mixing } \\
\text { Solar penetration }\end{array}$ & $\begin{array}{l}\text { Pacanowski and Philander (1981); unstable } \\
\text { regions: instantaneous homogenization; mar- } \\
\text { ginally stable regions: mixing coefficient increased } \\
\text { to } 50 \mathrm{~cm}^{2} \mathrm{~s}^{-1} \\
\text { Laplacian with eddy diffusivity of } 10^{7} \mathrm{~cm}^{2} \mathrm{~s}^{-1} \text { for } \\
\text { momentum and heat } \\
\text { Double exponential (Paulson and Simpson } 1977 \text { ) }\end{array}$ \\
\hline Advective transport & Heat and salt & Quicker algorithm of Leonard (1979) \\
\hline Initial conditions & & $\begin{array}{l}\text { At rest, with temperature and salinity profiles } \\
\text { equal to climatological annual average of Levitus } \\
\text { et al (1994) }\end{array}$ \\
\hline Time step & & $2700 \mathrm{~s}$ \\
\hline Spin-up time & & 50 years \\
\hline
\end{tabular}

data create difficulties in prescribing surface heat flux, precipitation and river discharge with sufficient accuracy, we have adopted the indirect course of applying heat and salt flux at the surface generated from 50-year climatological runs and relaxing model surface temperature and salinity to monthly climatology (Levitus et al 1994) as explained in Swathi et al (2000). The effectiveness of the indirect modelling in capturing the salinity distribution especially in the BoB is discussed in section 4 . The model is spun for 50 years from rest with initial temperature and salinity profiles based on annual climatological values.

\subsection{Biological model}

The present biological model is a 7-component nitrogen-based model incorporating process models of nonlinear growth, preferential grazing, nutrient recycling by bacteria, predation by higher trophic states, linear mortality and detritus sinking. It generally follows the scheme of Swathi et al (2000) and Sarmiento et al (1993) using the now-classical FDM model (Fasham et al 1990) within the euphotic layer and an empirical model of breakdown and regeneration below the euphotic layer (Sarmiento et al 1993). We have given a summary of the processes in figure 1 and the equations in Appendix I for ease of reference.

The FDM model uses a parameterization scheme for ammonium inhibition in which nitrate uptake by phytoplankton diminishes exponentially to zero with increasing ammonium at constant nitrate concentration (Wroblewski 1977). Numerous laboratory and field observations surveyed by Dortch (1990) do not support such a strong inhibition. The results of shipboard experiments on nitrogen dynamics by McCarthy et al (1999) led us to investigate in some depth the effect of ammonium inhibition in a mixed layer ecosystem using several parameterization schemes, termed as nitrogen kinetic relations in our earlier work (Sharada et al 2005). The present model uses the YS parameterization (Yajnik and Sharada 2003; equations (A12) and (A13) in Appendix I) of nitrate and ammonium uptake that has two important 


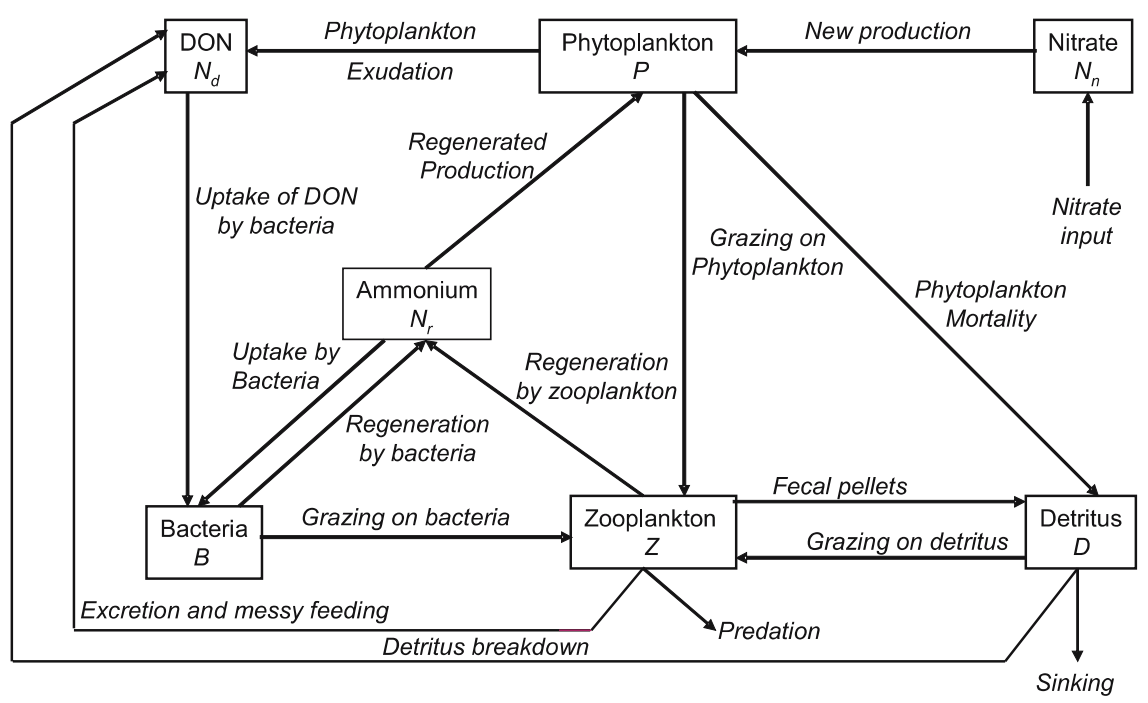

Figure 1. A schematic of the seven-component model of marine ecosystem (adapted from Fasham et al 1990).

properties. With increasing ammonium concentration, the nitrate uptake decreases hyperbolically to an asymptotic limit, which need not be zero. Secondly, the results of ammonium enrichment experiments at constant nitrate concentration can be made to collapse on a single curve by scaling nitrate uptake with its maximum value, which is consistent with the experiments of McCarthy et al (1999). These properties, termed as hyperbolicity and similarity, found in several disciplines like enzyme kinetics and boundary layer theory, are believed to be of fundamental significance (Yajnik and Sharada 2003). Also, the YS parameterization gives more realistic annual depth integrated primary productivity, primary productivity profiles at JGOFS stations, $f$-ratio and particulate export ratio than other parameterization schemes (Sharada et al 2005).

The biological model coupled with physical model (PBM) is started from the state the physical model (PM) has attained after 50 years. The initial condition of the biological variables is taken as in Swathi et al (2000). The biological model is found to approach an approximately periodic state in about four years.

\subsection{Chemical model}

Carbon chemistry is modelled broadly following Drange (1994, 1996) and Peng et al (1987). Two chemical prognostic variables (DIC and ALK) are introduced to represent the effect of the physical and biological processes on the carbon chemistry of sea water. The transport terms of their conservation equations (A21) and (A22) representing horizontal and vertical advective fluxes, diffusion, convective turbulent mixing have the same form as those for heat and salinity.

Figure 2(a) shows biological processes contributing to the source and sink terms in the conservation equation (A21) of DIC. Carbon fixation in new and regenerated production is modelled by the first two sinks. Calcification accompanying detrital sinking and implied by predation by higher trophic states removes $\mathrm{CaCO}_{3}$ and it is modelled by the third DIC sink. Release of DIC due to regeneration by bacteria and zooplankton is modelled by two source terms.

Consumption of $\mathrm{NO}_{3}^{-}$in new production and release of $\mathrm{NH}_{4}^{+}$in regeneration by zooplankton and bacteria increase ALK (figure $2 \mathrm{~b}$ ) and they are modelled by source terms in (A22). Consumption of $\mathrm{NH}_{4}^{+}$in regenerated production and uptake of $\mathrm{NH}_{4}^{+}$by bacteria decrease ALK and they are modelled by sinks of ALK. Finally, calcification accompanying sinking of detritus and predation implies removal of $\mathrm{Ca}^{2+}$ and is modelled by a sink in (A22). It is noteworthy that new production reduces DIC and increases ALK, while the regenerated production decreases both DIC and ALK.

Determination of air-sea carbon flux needs computation of $\mathrm{pCO}_{2}$ in the surface water. Dissolved inorganic carbon is partitioned into dissolved $\mathrm{CO}_{2}$, carbonic acid $\mathrm{HCO}_{3}^{-}$and $\mathrm{CO}_{3}^{2-}$. Carbon chemistry of sea water is modelled following Peng et al (1987) with minor modifications (see Swathi et al 2000). Boric acid is taken to be proportional to salinity. Phosphoric and silicic acids are not considered. Four equilibrium equations govern two dissociations of $\mathrm{CO}_{3}^{2-}$ and one each for dissociation of water and carbonic acid and there are three mass balances of DIC, ALK and Boron. 


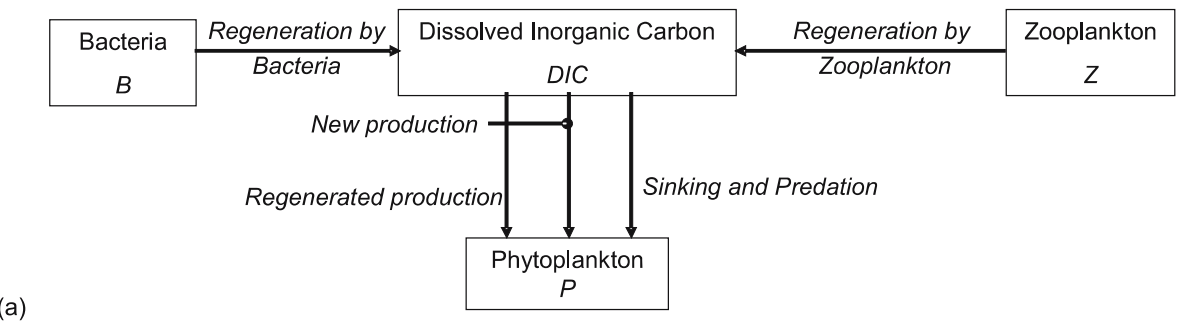

(a)

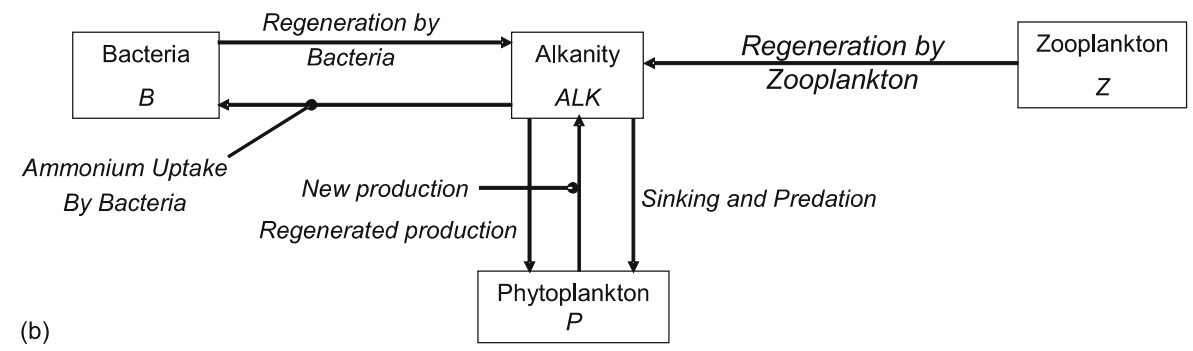

Figure 2. Schematic of effects of biological processes on conservation of (a) DIC and (b) ALK.

The prognostic equations for DIC and ALK (A21 and A22) close the otherwise undetermined system of seven nonlinear equations. As the equilibrium constants depend nonlinearly on temperature and salinity, sea surface $\mathrm{pCO}_{2}$ depends nonlinearly on two chemical and two physical variables.

The air-sea flux of $\mathrm{CO}_{2}\left(F_{C}\right)$ is determined by the equation

$$
F_{C}=k_{l} \alpha_{s}\left(\mathrm{pCO}_{2}^{\text {air }}-\mathrm{pCO}_{2}^{\text {sea }}\right),
$$

where $k_{l}$ is the piston or transfer velocity and $\alpha_{s}$ is the solubility of $\mathrm{CO}_{2}$ in sea water. $\mathrm{pCO}_{2}$ for air has been adjusted for $100 \%$ relative humidity and piston velocity (regulated by the turbulence at the air-sea interface and chemical reactions in the liquid phase) is calculated using Wanninkhof (1992) formulation. In contrast to other biological and chemical species which have zero air-sea fluxes, the flux $F_{C}$ is added to the top grid box while solving the DIC equation.

Calcification is modelled as follows. The net downward POC (assuming a Redfield ratio of 5.0) flux at each euphotic level is the sum of sinking detritus and instantaneously exported fraction of zooplankton mortality to higher predators. This net POC flux is multiplied by a rain ratio of 0.07 and the volumetric $\left(\mathrm{CaCO}_{3}\right)$ production rate is computed as a vertical divergence of this flux in the euphotic zone. Below the euphotic zone, $\mathrm{CaCO}_{3}$ is dissolved with a dissolution scale depth of $4000 \mathrm{~m}$.

The initial condition of the physical and the biological variables of $\mathrm{PBCM}$ is taken to be the state of the PBM at the end of four-year spin-up. The DIC and ALK fields are initialized by the objectively interpolated fields from $2^{\circ} \times 2^{\circ}$ atlas of Myrmehl and Drange (1998). The atmospheric $\mathrm{pCO}_{2}$ is held fixed at $360 \mu \mathrm{atm}$. We do not employ virtual fluxes for biological and chemical components. We report here the results for the fourth year. Issues related to adequacy of the spin-up are discussed in section 4 .

\section{Simulation experiments}

Our investigation begins with a PBCM simulation with the biological parameters given in Sharada et al (2005). The resulting surface $\mathrm{pCO}_{2}$ values on $65^{\circ} \mathrm{E}\left(64-66^{\circ} \mathrm{E}\right)$ transect between $10^{\circ} \mathrm{N}$ and $21^{\circ} \mathrm{N}$ are shown as Experiment A (whose parameters are given in Appendix II) in table 2, which also shows JGOFS cruise data during five months spanning all the seasons. The model values are derived from monthly snapshot results on the day closest to the cruise period. The noticeable discrepancy between them, it is hypothesized, is primarily due to excessive regeneration of ammonium by zooplankton, which is much larger than regeneration by bacteria. A minimalistic parametric study is designed to test the hypothesis and, if true, to reduce the discrepancy. Four key parameters are varied to reduce regeneration of ammonium by zooplankton in three distinct ways:

(1) by reducing zooplankton growth when its concentration is high,

(2) by increasing the share of predation in zooplankton mortality, and

(3) by additionally increasing zooplankton mortality.

In the first alternative (Experiment B), asymptotic grazing rate $g$ and half saturation constant 
Table 2. Observed and model surface $\mathrm{pCO}_{2}$ ( $\mu$ atm) nominally along $65^{\circ} \mathrm{E}$ transect.

\begin{tabular}{|c|c|c|c|c|c|c|}
\hline Season $^{1}$ & Duration $^{2}$ & US JGOFS ${ }^{3}$ & $\operatorname{Exp} A^{4}$ & $\operatorname{Exp} B^{4}$ & $\operatorname{Exp} C^{4}$ & $\operatorname{Exp} D^{4}$ \\
\hline Late NEM & $\begin{array}{l}\text { J: } 11,17-23 \text { January } \\
\text { M: } 1 \text { February }\end{array}$ & 359-404 & $484-562$ & $455-525$ & $422-468$ & $402-423$ \\
\hline SIM & $\begin{array}{l}\text { J: } 16,22-29 \text { March } \\
\text { M: } 3 \text { April }\end{array}$ & $346-365$ & $482-545$ & $452-477$ & $423-457$ & $408-426$ \\
\hline SWM & $\begin{array}{l}\text { J: } 22 \text { July, } \\
28 \text { July- } 3 \text { August } \\
\text { M: } 3 \text { August }\end{array}$ & 359-392 & $474-540$ & $464-537$ & $420-457$ & $392-409$ \\
\hline FIM & $\begin{array}{l}\mathrm{J}: 4,5 \text { November, } \\
\text { 8-12 November } \\
\mathrm{M}: 2 \text { November }\end{array}$ & $358-384$ & $491-558$ & $473-535$ & $436-461$ & $408-418$ \\
\hline Early NEM & $\begin{array}{l}\text { J: } 3 \text { December, } \\
\text { 9-15 December } \\
\text { M: } 2 \text { December }\end{array}$ & $358-382$ & $497-577$ & $474-552$ & $432-471$ & $404-426$ \\
\hline
\end{tabular}

${ }^{1}$ See the definitions of seasons given in section 4.

${ }^{2} \mathrm{~J}$ and $\mathrm{M}$ refer to JGOFS and model.

${ }^{3} \mathrm{pCO}_{2}$ in water measurements along ship track in JGOFS cruise ttn- 049 at 8 stations between $10^{\circ} \mathrm{N}-20^{\circ} \mathrm{N}$.

${ }^{4}$ Model $\mathrm{pCO}_{2}$ values at 25 grid points $0.4^{\circ}$ apart in $10^{\circ} \mathrm{N}-20^{\circ} \mathrm{N}$.

of grazing $k_{3}$ are both reduced from 1 to 0.6 , thus keeping their ratio constant so as to leave grazing rate unaltered when zooplankton concentration is very low, and leaving all other parameters unchanged. In the second alternative (Experiment C), detrital fraction $\gamma_{4}$ of zooplankton mortality due to predation is increased from 0.33 to 0.5 keeping all other parameters constant. In the third alternative (Experiment D), in addition to increasing $\gamma_{4}$, zooplankton mortality $\mu_{5}$ is also increased from $0.05 \mathrm{~d}^{-1}$ to $0.1 \mathrm{~d}^{-1}$ without changing any of the remaining parameters. The relevant parameter values of the four experiments are shown in Appendix II.

Table 2 gives the surface $\mathrm{pCO}_{2}$ values of all the four experiments and the JGOFS data. They clearly show that Experiment D is the most effective in reducing the discrepancy. We therefore call it the standard run and present its results in the subsequent sections.

\section{Results and discussion}

We begin by examining certain aspects of the modelling methodology before examining the results of the standard run and the abiotic run. We first begin by summarising the PM performance in capturing temperature and salinity in the upper ocean, which has been discussed at length in Sharada et al (2005) (section 2.3). The restoring heat flux at the surface is small $\left(<\sim 2 \mathrm{~W} \mathrm{~m}^{-2}\right)$ indicating that the surface conditions are stable with little drift. The model mixed layer depth in January (Sharada et al 2005, figure 5) agrees with Levitus climatology in most places within about 20 meters. The noticeable discrepancy in the region of the low level Findlater jet $(>\sim 20$ meters in July) is probably due to the contribution of high frequency monsoon winds being excluded in monthly forcing leading to the underestimation of wind stress curl.

Model surface salinity compares qualitatively well in January and July (Sharada et al 2005, figure 7) in the AS with Levitus et al (1994). Both models as well as Levitus have the highest salinity in January in northwest AS. There are however local discrepancies. For example, model salinity is lower in the northeast BoB by 1 and $0.5 \mathrm{psu}$ in January and July. Recent observations in the BoB have shown transient stratification effects in surface waters like fresh water plume (Gopalkrishna et al 2002) and the formation of barrier layer (Vinaychandran et al 2002) in north BoB during July-August as major rivers swollen by heavy rainfall in their catchment areas discharge large amounts of fresh water, which then spreads across the bay. For example, the latter observations at the station $\mathrm{TS} 2\left(89^{\circ} \mathrm{E}, 17^{\circ} 30^{\prime} \mathrm{N}\right)$ show a sharp drop in salinity $(\sim 4 \mathrm{psu})$ followed by slow rise $(\sim 1 \mathrm{psu})$ during 27 July 1999 to 6 August 1999 in upper 15 meters. Our model shows a fall in monthly salinity $(\sim 2.5 \mathrm{psu})$ in top 20 meters from July to August at $88^{\circ} 30^{\prime} \mathrm{E}, 17^{\circ} 30^{\prime} \mathrm{N}$. There is also a local discrepancy by about 1 psu near the southern tip of the west coast of India in January probably due to the model seasonal transport of low salinity water from BoB (Shenoi et al 2005) and its accumulation near Lakshadweep islands, although Levitus et al (1994) do not reveal this local feature possibly because of interpolation errors with 
limited data, unlike more recent climatological data (World Ocean Atlas 2005).

An ecosystem model using nitrogen as a single currency cannot do justice to modelling of dissolved organic matter (Anderson and Williams 1998; Anderson and Pondaven 2003), which needs carbon as an additional currency; nor can it deal with iron limitation that needs bioavailable iron as another currency.

The issue of modelling of iron limitation in the north Indian Ocean needs further discussion. Interest in the iron limitation on phytoplankton growth has increased considerably after the iron hypothesis of Martin (1990). Jickells et al (2005) have estimated on the basis of three extensivelyvalidated models that Indian Ocean receives $25 \%$ of global dust deposition of $450 \mathrm{Tg}$ year ${ }^{-1}$. Their results also show that the average dust deposition rate drops by an order of magnitude (from $\sim 2$ to $\sim 0.2 \mathrm{gm} \mathrm{m}^{-2}$ year $^{-1}$ ) in $5^{\circ} \mathrm{N}-25^{\circ} \mathrm{S}$. Thus most of the dust deposition occurs in the north Indian Ocean.

Moore et al (2002b) have compared observations of dissolved iron in major ocean basins. They find that concentration of dissolved iron in AS $\left(10-23^{\circ} \mathrm{N} ; 57-69^{\circ} \mathrm{E}\right)$ is larger at 430 $2930 \mathrm{pM}$ than almost all the sites in north Pacific $\left(9-56^{\circ} \mathrm{N} ; 122-158^{\circ} \mathrm{W}\right)$, equatorial Pacific $\left(6^{\circ} \mathrm{S}-9^{\circ} \mathrm{N}\right.$; $\left.105-140^{\circ} \mathrm{W}\right)$, north Atlantic $\left(36-59^{\circ} \mathrm{N} ; 20-72^{\circ} \mathrm{W}\right)$, and all the sites in southern Ocean, notably excluding two areas $\left(69-46^{\circ} \mathrm{S}, \sim 6^{\circ} \mathrm{W} ; 77-74^{\circ} \mathrm{S}\right.$, $\left.182-168^{\circ} \mathrm{W}\right)$. Recent surveys of dissolved iron concentration in the World Ocean also show clearly that dissolved iron concentrations in the north Indian Ocean are amongst the highest in the world (Moore and Broucher 2007; figure 2).

Recently, Wiggert et al (2006) have investigated iron limitation in the Tropical Indian Ocean $\left(25^{\circ} \mathrm{S}-25^{\circ} \mathrm{N} ; 40^{\circ} \mathrm{E}-125^{\circ} \mathrm{E}\right)$ using an ecosystem model coupled to a reduced gravity model with $19 \sigma$-layers below the mixed layer. They suggest that north Indian Ocean has a tendency towards seasonal iron limitation in west $\mathrm{AS}\left(<60^{\circ} \mathrm{E}\right)$ in three seasons (NEM, SWM, FIM), near southwest Indian coast in two seasons (SWM, FIM), near Indonesian coast in SIM, and in south $\mathrm{BoB}\left(4-6^{\circ} \mathrm{N}\right.$, $<98^{\circ} \mathrm{E}$ ) in NEM. Several issues related to this work need elucidation at present, possibly by further investigation: whether there is any experimental support for the assumed iron limitation function of phytoplankton uptake; how bio-available iron is cycled through the ecosystem model; and whether there is any experimental support for the reported seasonal iron deficiency near Somalia coast and southwest Indian coast.

The modelling of bio-available iron in ocean seem to require tracking of bio-available iron through the ecosystem, which in turn needs aggregating
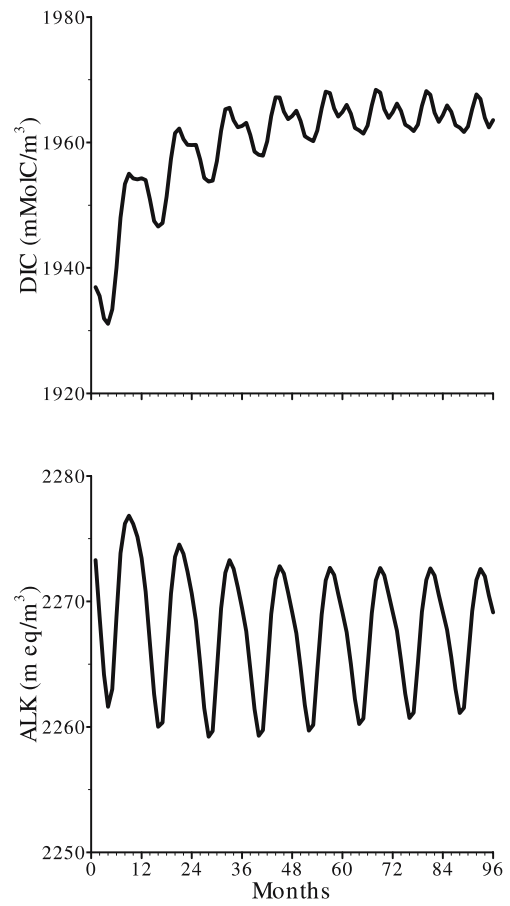

Figure 3. Evolution of monthly DIC $\left(\mathrm{mmolC} / \mathrm{m}^{-3}\right)$ and $\operatorname{ALK}\left(\mathrm{meq} / \mathrm{m}^{-3}\right.$ ) averaged over the top 20 meters in the north Indian Ocean $\left(0^{\circ}-27^{\circ} \mathrm{N} ; 42^{\circ}-100^{\circ} \mathrm{E}\right)$ during the first eight years of the PBCM standard run.

trophic states into functional groups and tracking of several chemical elements as Moore et al (2002a) have shown. Such a modelling exercise substantially increases model complexity and uncertainty on account of considerable increase in the number of parameters. Considering the present focus on the north Indian Ocean, we considered it prudent to invoke Occam's razor and exclude modelling of iron limitation, which is reasonable in view of available model dust deposition rates as well as observations of dissolved iron.

Figure 3 shows the evolution of monthly DIC and ALK averaged over the top 20 meters in the north Indian Ocean $\left(0^{\circ}-27^{\circ} \mathrm{N} ; 42^{\circ}-100^{\circ} \mathrm{E}\right)$. It clearly indicates that these two key chemical variables approach, in the model basin on an average, to an approximately periodic state in the upper 20 meters. This behaviour is to be expected as the DIC and ALK initial conditions are based on climatological atlas. The figure also shows that their seasonal anomaly is small compared to the annual mean. Consequently, it is these small seasonal changes in surface DIC and ALK that determine seasonal variability of surface $\mathrm{pCO}_{2}$ and hence seasonal variability of air-sea carbon flux, and they are significantly influenced by marine ecosystem in the euphotic layer. Finally, the long term effects of deeper circulation are indirectly built upfront into the simulation 
as a consequence of the climatological initial conditions. Short-duration PBCM runs thus do not preclude the long-term effects of deep ocean circulation. We refrain from spinning the model for longer periods as the crude modelling of regeneration below the euphotic layer results in small but cumulative errors in nitrate and ammonium, which slowly spread to the euphotic layer as the simulation progresses. Also, propagation of errors of sponge boundary conditions into the interior generally leads to restriction of the duration of runs of regional models. This restriction is important in the present work as only temperature and salinity are relaxed to climatological conditions in $5^{\circ}-15^{\circ} \mathrm{S}$.

We now turn to evaluating the results of the standard run by comparing them with other observations. Since PBCM based primary productivity has already been evaluated in the AS against JGOFS data in Sharada et al (2005), we restrict here to the comparison of the primary productivity in the $\mathrm{BoB}$ and the observations of BoBPS cruises. Figure 4 shows monthly model primary productivity from the standard run (Exp D) integrated over the euphotic zone $(120 \mathrm{~m})$ along the $88^{\circ} \mathrm{E}$ transect for April, July and September along with BoBPS cruise data. The standard run results compare moderately well with the BoBPS data between $6^{\circ} \mathrm{N}$ and $16^{\circ} \mathrm{N}$. The discrepancy near $20^{\circ} \mathrm{N}$ is most probably due to stratification effects resulting from large river discharge and precipitation which is a well known difficulty that almost all models face in the north BoB.

Turning our attention to chemical variables, we next compare the results of the standard run for the zonal transect along $9^{\circ} \mathrm{N}\left(8.5-9.5^{\circ} \mathrm{N}\right)$ in the AS and $10^{\circ} \mathrm{N}\left(9.5-10.5^{\circ} \mathrm{N}\right)$ in the BoB with observations of WOCE I1 cruise along nominally $9^{\circ} \mathrm{N}$ in AS and nominally $10^{\circ} \mathrm{N}$ in $\mathrm{BoB}$, which were analyzed by Goyet et al (1999). We have chosen September average as the WOCE I1 cruise took place during August 29 to October 16, 1995. Figure 5(a) gives contours of September average of DIC and ALK in the $9^{\circ} \mathrm{N}$ vertical section in AS up to $500 \mathrm{~m}$ depth. They compare quite well, especially in the upper $\sim 200$ meters, with WOCE I1 data given in figure 3(a) and 3(b) of Goyet et al (1999). An interesting feature of model DIC in figure $5(\mathrm{a})$ is a $\sim 50$-meter deep subsurface layer shoaling eastward across which DIC changes by $\sim 150 \mathrm{~m} \mathrm{~mol} \mathrm{C} \mathrm{m}^{-3}$. Figure 3 of Goyet et al (1999) also shows a similar layer at almost the same location and with about the same gradient. The September average of meridional velocity at this section, not given here, shows at the same location a shear layer in meridional velocity separating upper faster southward flow from lower slower southward flow, suggesting that the eastward monsoonal flow east of $60^{\circ} \mathrm{E}$ in
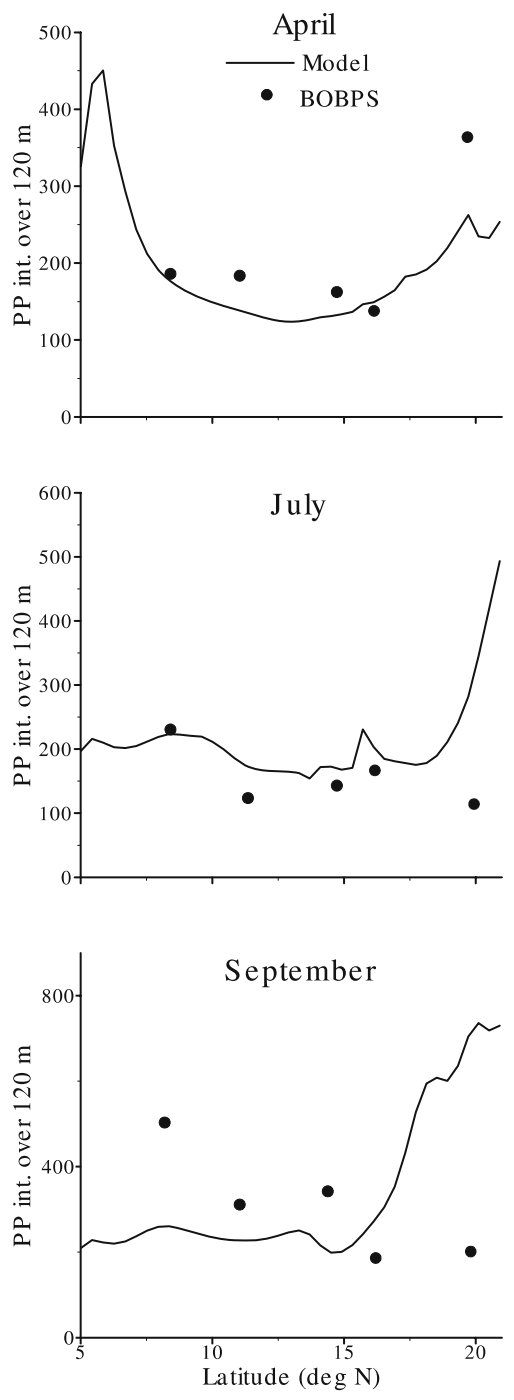

Figure 4. Depth integrated primary productivity $\left(\mathrm{mgC} / \mathrm{m}^{2} /\right.$ day) values from model simulations (Exp D) compared with the data of Bay of Bengal Process Studies during April (SK191 - 10 April to 10 May 2003), July (SK166 - 6 July to 2 August 2001) and September (SK182 14 September to 12 October 2002).

late SWM season brings with it higher DIC and ALK. Both observed and model surface ALK show a high around $66 / 67^{\circ} \mathrm{E}$. Goyet et al (1999) have noted linear correlation of alkalinity with salinity, and their figure 6(b) indeed shows salinity high around $67^{\circ} \mathrm{E}$.

Similarly, figure 5(b) gives model DIC and ALK contours for September along $10^{\circ} \mathrm{N}$ transect in the BoB. It also shows a westward shoaling $\sim 50 \mathrm{~m}$ deep layer across which DIC changes by $\sim 200 \mathrm{~m} \mathrm{~mol} \mathrm{C} \mathrm{m}^{-3}$. The layer across which ALK rises by $\sim 50 \mathrm{~m} \mathrm{eq}^{-3}$ becomes thinner as it shoals westward. Comparable layers are also seen in figure 4(a) and (b) of Goyet et al (1999).

As Goyet et al (1999) have pointed out, the zonal contrast of $\sim 170 / 150 \mathrm{~m} \mathrm{~mol} \mathrm{C} \mathrm{m}^{-3}$, which 


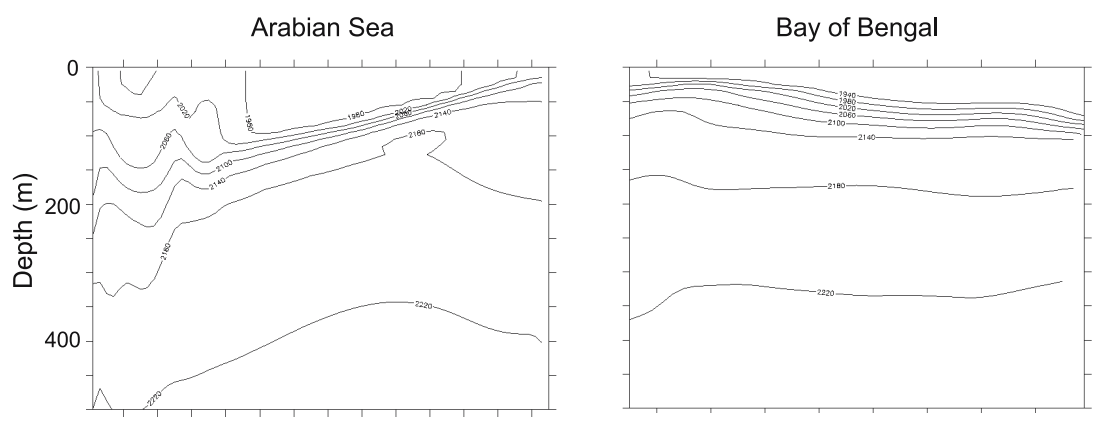

Dissolved Inorganic Carbon
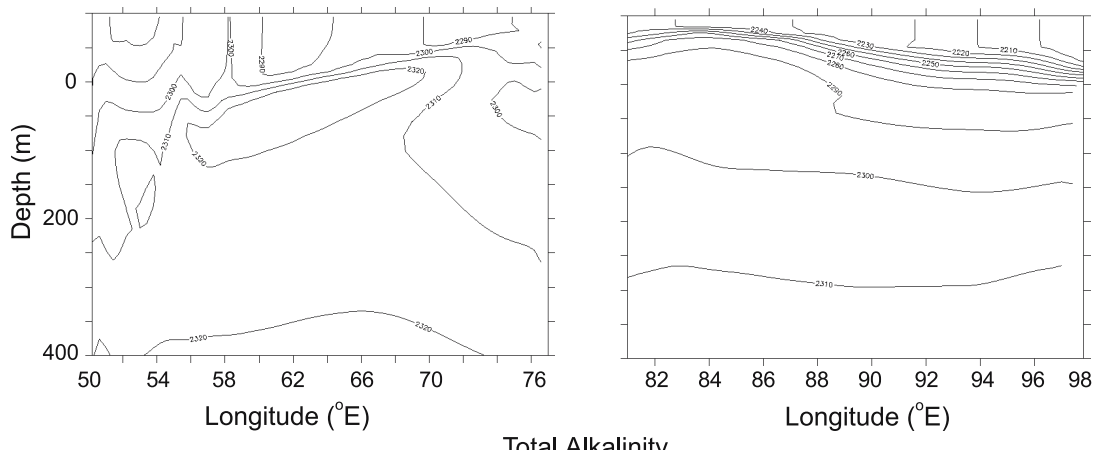

Total Alkalinity

Figure 5. DIC $\left(\mathrm{mmolC} / \mathrm{m}^{-3}\right)$ and $\operatorname{ALK}\left(\mathrm{meq} / \mathrm{m}^{-3}\right)$ along the $9^{\circ} \mathrm{N}$ transect in the Arabian Sea and along the $10^{\circ} \mathrm{N}$ transect in the Bay of Bengal in the upper $500 \mathrm{~m}$.
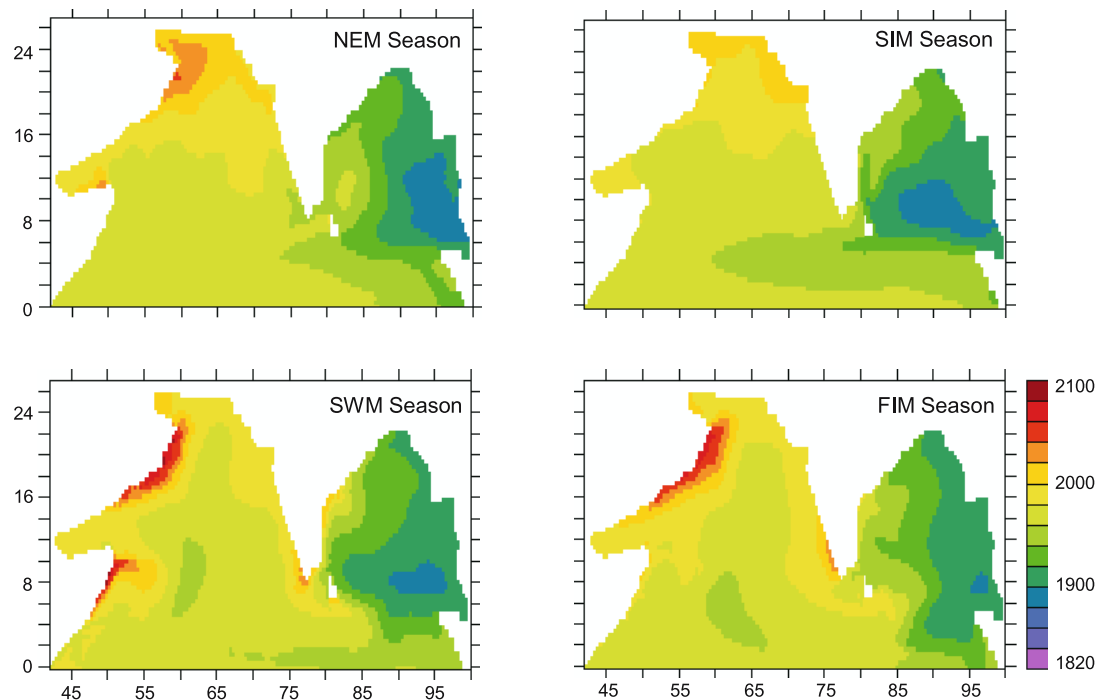

Figure 6. Seasonally averaged model surface DIC $\left(\mathrm{mmolC} / \mathrm{m}^{-3}\right)$ in the north Indian Ocean in the standard run.

both the WOCE I1 observations and model DIC show, is larger than typical zonal contrast $\left(\sim 100 \mathrm{~m} \mathrm{~mol} \mathrm{C} \mathrm{m}^{-3}\right)$ over comparable distances in other oceans.

Notwithstanding excellent qualitative agreement between the model results and observations, we now examine critically the discrepancies in the September values of model and observed DIC, ALK and salinity with a view to determine where the model could be improved. While the zonal contrast in model surface DIC is slightly smaller than in the WOCE observations, the contrast in model surface ALK $\left(\sim 100 \mathrm{meq} \mathrm{m}^{-3}\right)$ is significantly lower than in the WOCE observations $\left(\sim 250 \mathrm{~m} \mathrm{eq} \mathrm{m}^{-3}\right)$. Zonal contrast in salinity in the standard run ( $3.7 \mathrm{psu})$ is also smaller than in WOCE I1 observations (4 psu). 

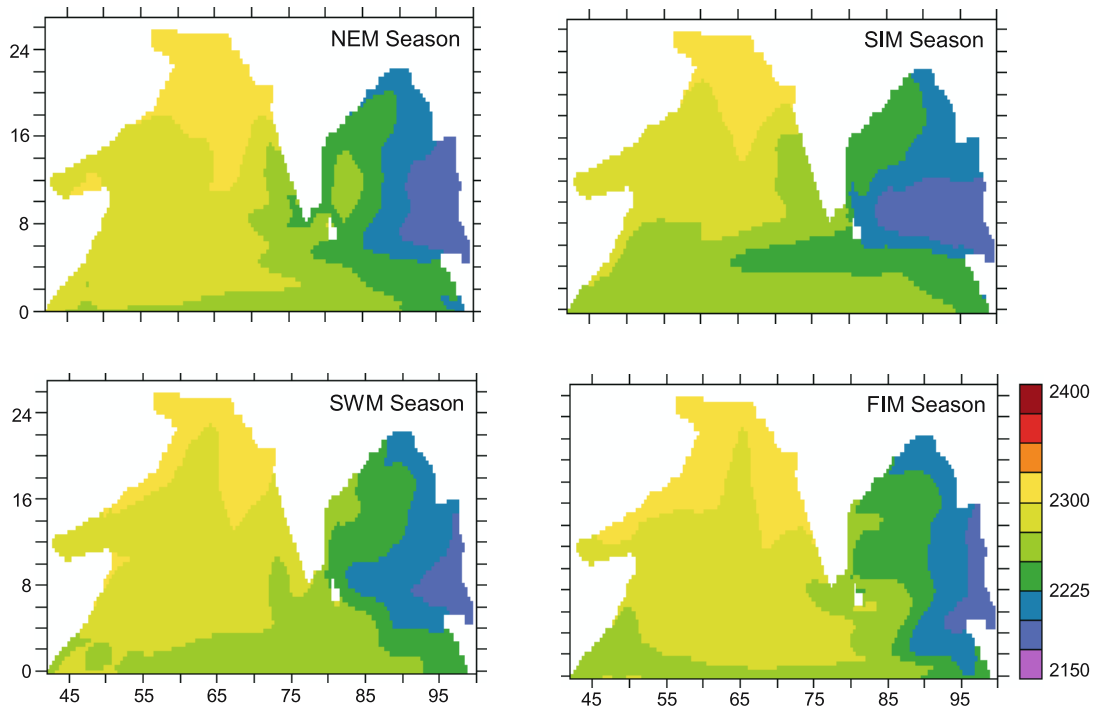

Figure 7. Seasonally averaged model surface ALK $\left(\mathrm{meq} / \mathrm{m}^{-3}\right)$ in the north Indian Ocean in the standard run.

The preceding comparisons of the standard run results of (a) surface $\mathrm{pCO}_{2}$ results with JGOFS data, (b) column primary productivity with BoBPS data and (c) surface DIC, ALK and salinity with WOCE I1 data, taken together, lead us to conclude that the standard run qualitatively captures the observed trends in the AS and $\mathrm{BoB}$, quantitative differences probably being due to well known modelling difficulties of stratification effects, particularly in the north BoB.

It is expedient to extract seasonal trends from monthly results of ocean models, by dividing a year in four quarterly seasons. While the traditional division of a calendar year in the usual four quarters, the first quarter being January-March, is appropriate for a global study of seasonal ocean cycles, the extraordinary effect of reversing monsoon winds on the seasonal cycles in the north Indian Ocean calls for a different division. We use, in the subsequent presentation of the seasonal trends given by the standard run, four seasons, which are termed as SWM Season (June-August), FIM Season (September-November), NEM Season (December-February) and SIM Season (MarchMay). Bates et al (2006a) also use this division with a different nomenclature. Definitions of seasons however differ considerably in the literature. Traditional seasons (e.g., Sabine et al 2000), seasons beginning in the middle of the month (e.g., Smith et al 1998) and seasons of durations other than three months (e.g., Sarma et al 2003) have been used. Probable reason for this diversity is wide variation in climatological onset and withdrawal dates of SW and NE monsoons in the north Indian Ocean. Consequently, no definition of seasons, of any duration, can ensure that the seasons begin and end simultaneously with the monsoons or transitions everywhere in the north Indian Ocean. Our terminology is intended to suggest the dominant monsoon/transition, in the model basin as a whole.

Seasonal averages of surface DIC (figure 6), show that zonal contrast between the AS and the $\mathrm{BoB}$, which was earlier found in September model values and WOCE I1 observations along $9 / 10^{\circ} \mathrm{N}$ transect, occurs at all latitudes in the model basin and in all the seasons. As pointed out earlier, the zonal differences in surface DIC are larger in the northern Indian Ocean than elsewhere over comparable distances. Why do the eastern and western parts of the model basin have such a large zonal contrast? The prime reason is that coastal upwelling in Oman and Somalia coast, upwelling in the Somali jet region during SWM season, and enhanced vertical mixing in north AS in NEM season bring up higher DIC from depth. The sharp zonal contrast in surface ALK between the AS and $\mathrm{BoB}$, found earlier along $9 / 10^{\circ} \mathrm{N}$ in September, also occurs over the whole model basin and in all seasons (figure 7). Since ALK is closely related to salinity, heavy precipitation, heavy cloud cover, and heavy river discharge lead to extensive stratification in the BoB throughout the year and contributes to the contrast. Also, the effect of winter cooling in NEM season is noteworthy in the north AS.

The advective interaction between the AS and $\mathrm{BoB}$ is rather complex due to (a) the semiannual narrow Wyrtki jet, (b) the seasonal equatorial undercurrent and (c) the seasonal flow south of Sri Lanka and, to a much smaller extent, the seasonal flow through the Gulf of Mannar and the Palk Strait. The first two are confined to $\sim 2^{\circ} \mathrm{S}-\sim 2^{\circ} \mathrm{N}$ 

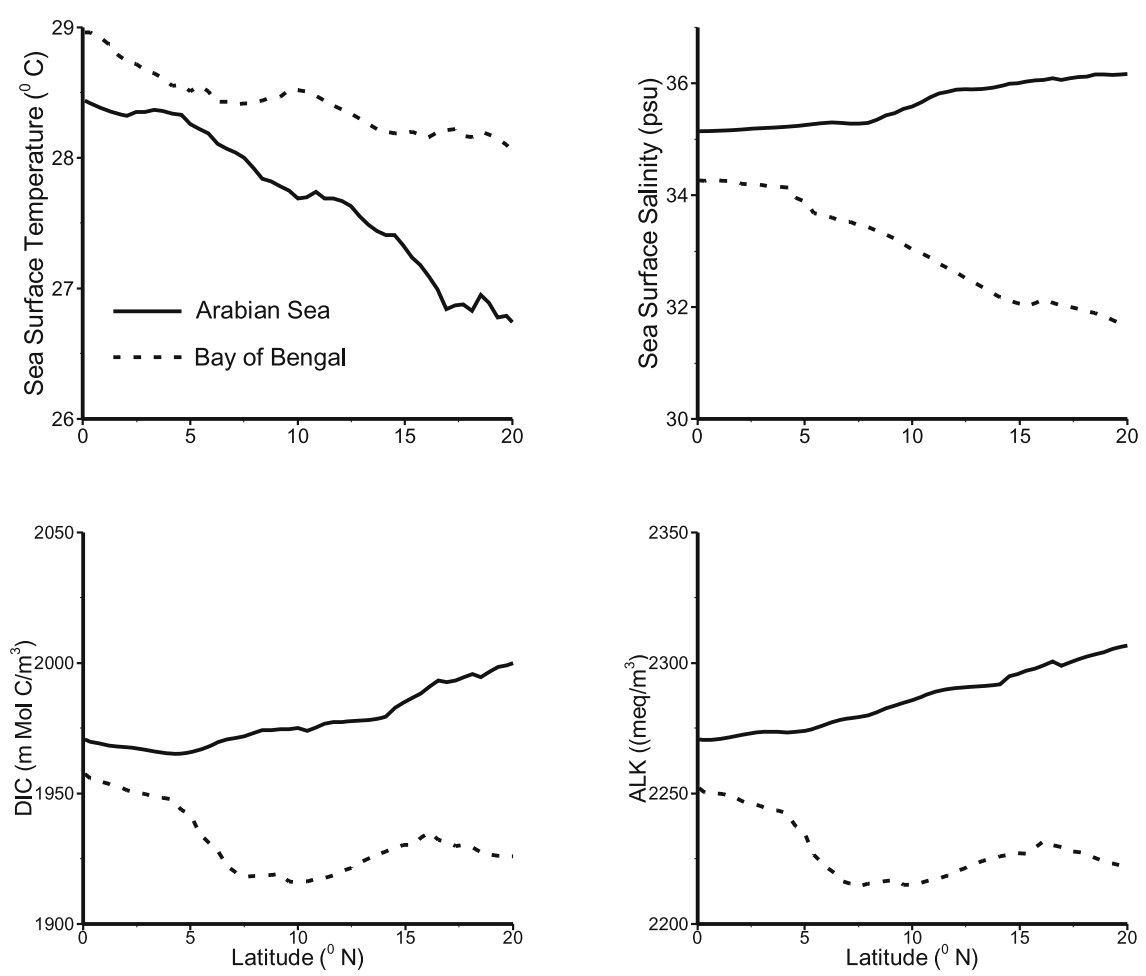

Figure 8. Meridional variation of zonal averages of annual mean of SST $\left({ }^{\circ} \mathrm{C}\right)$, salinity (psu), DIC $\left(\mathrm{mmolC} / \mathrm{m}^{-3}\right)$ and $\mathrm{ALK}$ $\left(\mathrm{meq} / \mathrm{m}^{-3}\right)$ between the Arabian Sea $\left(42-78^{\circ} \mathrm{E}\right)$ and Bay of Bengal $\left(78-100^{\circ} \mathrm{E}\right)$.

and they transport fresh water westward or saline water eastward depending on the season. In SWM season, east-flowing Southwest Monsoon Current (SMC) flows south of Sri Lanka. It is supplied partly by the outflow of south flowing West India Coastal Current (WICC) around Lakshadweep Low (LL) and partly by the outflow of Somali Current (SC) at low latitudes. Its outflow supplies East Indian Current bifurcating at $\sim 10^{\circ} \mathrm{N}$ after circulating around Sri Lanka Dome (SD) and generating eddies contributing to vertical and horizontal transport of tracers in the southwest BoB (Vinaychandran et al 2004). Thus more saline waters are advected from the AS at low latitudes, southeast AS and southwest Indian coast to the $\mathrm{BoB}$ at low latitudes, southeast $\mathrm{BoB}$ and southeast Indian coast. In NEM season, west-flowing Northeast Monsoon Current (NMC) flows south of Sri Lanka. It is supplied partly by southeast flowing East India Coastal Current (EICC) and its outflow partly supplies north flowing WICC after turning around Lakshadweep High (LH) and partly flows eastwards supplying Somali Current (SC). Thus there is transfer of fresher water in a reverse direction in NEM season. (See for a detailed discussion Schott and McCreary 2001; and Shankar et al 2002).

Figure 8 shows how annual mean of zonally averaged temperature, salinity, DIC and ALK in the top 20 meters vary with latitude in AS $\left(42-78^{\circ} \mathrm{E}\right)$ and in $\mathrm{BoB}\left(78-100^{\circ} \mathrm{E}\right)$. Clearly, annual mean of zonal contrast between the $\mathrm{AS}$ and $\mathrm{BoB}$ in surface physical and carbon variables is significant throughout the year and increases with latitude. The AS and BoB are indeed well known for their opposite meridional gradients in surface salinity.

Higher SST, lower salinity and DIC of surface water translate into generally lower $\mathrm{pCO}_{2}$ in the $\mathrm{BoB}$ than in AS (figure 9). The modelled seasonally averaged carbon flux is shown in figure 10. (Note that negative sign implies efflux into the atmosphere and the scale in SWM season (25-350 $\left.\mathrm{g} \mathrm{C} \mathrm{m}^{-2} \mathrm{yr}^{-1}\right)$ differs from the scale in the remaining seasons $\left.\left(5-40 \mathrm{~g} \mathrm{C} \mathrm{m}^{-2} \mathrm{yr}^{-1}\right)\right)$. The temporal and spatial variability is a bit more complex for the carbon flux than surface $\mathrm{pCO}_{2}$, as the transport across the ocean surface also varies approximately as the square of the wind speed. The net result is that the Findlater jet amplifies the effect of $\mathrm{pCO}_{2}$ differential across the air-sea interface in the AS area stretching from the coast of Somalia to the central western coast of India and yields the strongest outgassing of $\mathrm{CO}_{2}$ in the north Indian Ocean. Also, the standard run gives outgassing everywhere in the north Indian Ocean and in all seasons, except for a small region in the northeast $\mathrm{BoB}$ in NEM season. 

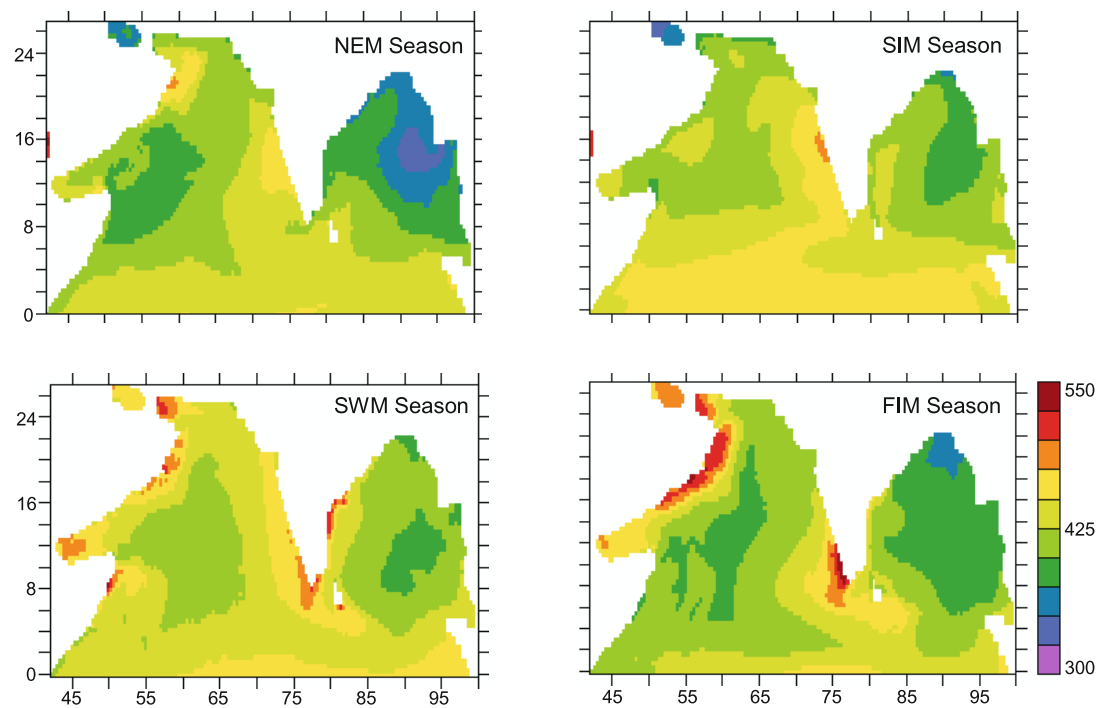

Figure 9. Spatial and temporal variation of surface $\mathrm{pCO}_{2}$ ( $\mu \mathrm{atm}$ ) obtained from model simulation.
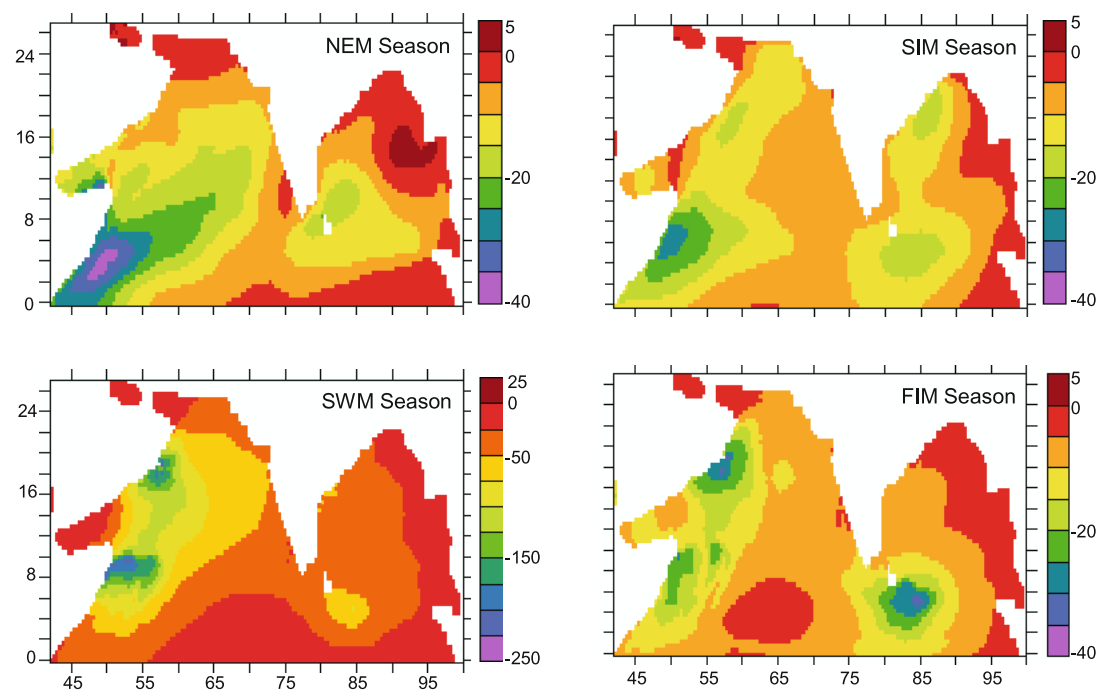

Figure 10. Spatial and temporal variation of surface carbon flux $\left(\mathrm{gC} / \mathrm{m}^{2} /\right.$ year $)$ from atmosphere to ocean obtained from model simulation (Note that negative values indicate outgassing from the ocean.).

Seasonally averaged carbon fluxes in the north Indian Ocean derived from Takahashi et al (1999) show:

- most intense outgassing of carbon off the Oman coast in SWM season,

- less intense outgassing in FIM season, with peak off the Oman coast,

- considerably lower outgassing in the other two seasons with peak near the Somali coast.

The zonal contrast between $\mathrm{AS}$ and $\mathrm{BoB}$ in Takahashi et al (1999) is roughly similar to PBCM standard run results. However, maximum outgassing in the standard run in SWM season is larger by about 100-150\%. Our results are based on
Wanninkhof (1992) relation for $k_{l}$ and Hellerman and Rosenstein (1983) winds, while Takahashi data are based on a different $k_{l}$ formulation and Esbensen and Kushnir (1981) winds. Given the quadratic dependence of $k_{l}$ on wind speeds, the coarser spatial resolution $\left(4^{\circ} \times 5^{\circ}\right)$ in Takahashi data could also be a significant factor, as the wind averaged over a larger area would be weaker leading to significant reduction of the peak carbon flux in Takahashi data, especially in SWM season.

Monthly distribution of air-sea carbon flux given in Bates et al (2006a) shows that whole of northern Indian Ocean is outgassing except eastern BoB during NEM months (i.e., December-February). Higher sea to air fluxes are seen in the western 

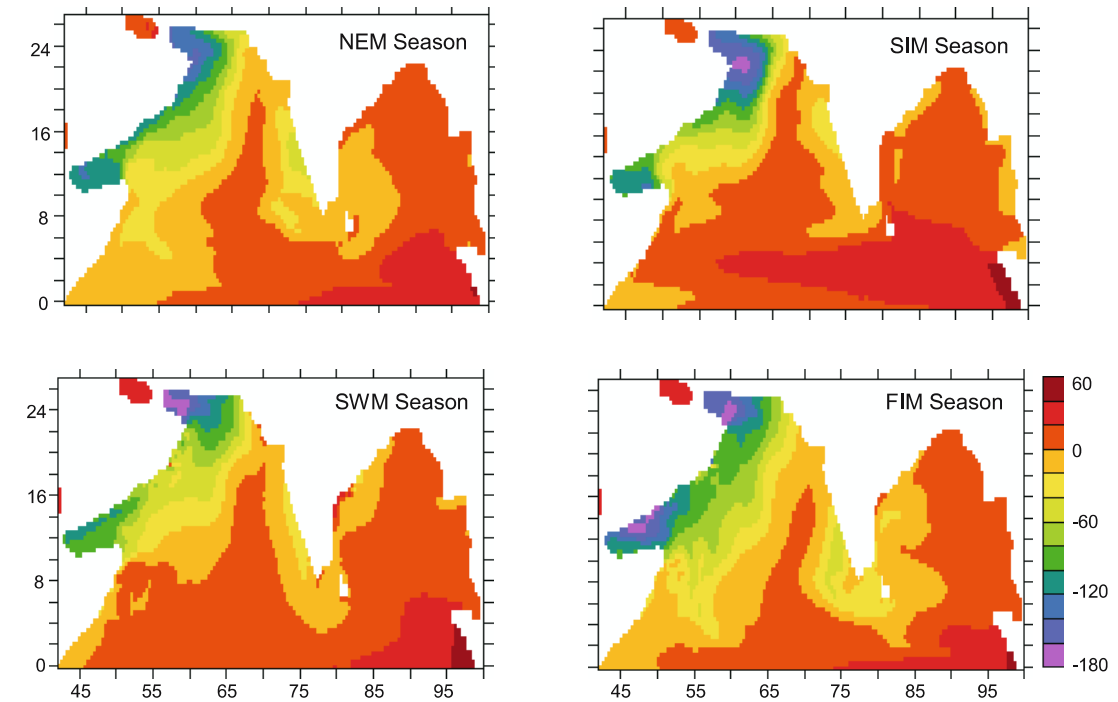

Figure 11. Spatial and temporal variation of difference in $\mathrm{pCO}_{2}$ ( $\mu$ atm) between biotic and abiotic simulations.

AS and southeast coast of India during DecemberFebruary and June-August where upwelling is high. Sea-to-air carbon flux is lowest during SIM in AS. All these features are captured by the model simulations. Higher sea to air fluxes are obtained from the standard run during SIM and FIM in BoB, but Bates et al (2006a) obtain highest sea to air carbon flux during SWM and FIM in BoB.

\section{Role of biology in the air-sea carbon transfer}

We have seen in section 2.3 how the biological processes and physical and chemical processes are intertwined in the transport equations of DIC and ALK. To isolate the effect of biology, we use the metaphor of solubility and biological pumps and pose the question: What are the relative effects of the biological and solubility pumps on the seasonal carbon cycle in the north Indian Ocean?

We devise a modelling device to address the above question. It consists of a hypothetical PBCM simulation in which the biological pump is turned off from the beginning of the simulation, keeping the initial conditions on physical and chemical variables the same as in the standard run. We call this simulation the abiotic run to indicate that the biological processes do not contribute to seasonal variability. The seasonal variability in the abiotic run thus depends only on the solubility pump on a seasonal time scale. Note that since the initial conditions are taken from climatological atlases, the biological effects over all longer time scales are implicitly built into all the runs of PBCM, including the abiotic run. Thus the difference between the standard run and the abiotic run may be considered as a measure of the effect of biological pump on the seasonal scale. We investigate this measure for important chemical variables to obtain insight in the role of biological processes in the carbon cycle in the north Indian Ocean.

We first note that the standard run and the abiotic run have the same temperature and salinity fields. So the difference in surface $\mathrm{pCO}_{2}$ is entirely due to the difference in surface DIC and ALK. Figure 11 shows the spatial variability of the difference in surface $\mathrm{pCO}_{2}$ in the four seasons. The seasonally averaged surface $\mathrm{pCO}_{2}$ in the standard run is lower than the abiotic run by $100 \mathrm{ppm}$ or more in high productivity regions, like the coastal regions of Arabia and, to a smaller extent, in the west and the east coast of India, in all the four seasons. This expected trend is clearly the consequence of vigorous carbon fixation in the high productivity regions, where upwelling feeds nutrients to the surface waters.

The effect of biological pump on the seasonal air-sea carbon flux varies spatially and seasonally as shown in figure 12. In SWM season, there is spectacular decrease in the outgassing of carbon roughly along the axis of Findlater Jet (Smith et al 1998) in the northwestern AS. Here strong upwelling brings up not only nutrients but also higher DIC from deeper waters and leads to a very large outgassing in the abiotic run. But the biological uptake in the standard run considerably offsets the DIC increase in the upwelled waters. Vigorous carbon fixation increases new production substantially, thereby decreasing DIC and changing ALK marginally. Resulting reduction in $\mathrm{pCO}_{2}$ tends to lower the outgassing. But the effect of upwelling is so strong that even after the reduction 

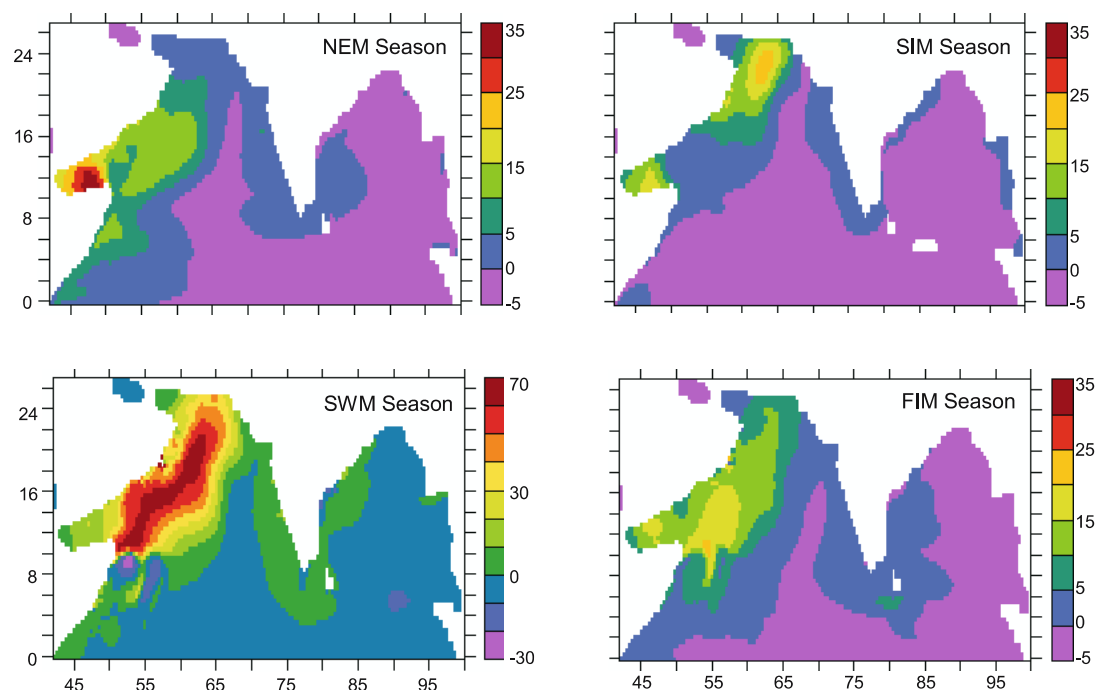

Figure 12. Spatial and temporal variation of difference in carbon flux $\left(\mathrm{gC} / \mathrm{m}^{2} /\right.$ year $)$ between biotic and abiotic simulations. (A positive value of difference indicates decrease in outgassing.).

Table 3. Carbon flux from ocean to atmosphere over a year (PgC/Year).

\begin{tabular}{|c|c|c|c|c|}
\hline & Region & Abiotic (ab) & Biotic (bi) & $\begin{array}{c}\% \text { Difference } \\
100 *(\text { bi-ab)/ab }\end{array}$ \\
\hline Annual & $\begin{array}{l}\text { Model basin } \\
\text { AS } \\
\text { BoB }\end{array}$ & $\begin{array}{l}0.26 \\
0.207 \\
0.053\end{array}$ & $\begin{array}{l}0.226 \\
0.166 \\
0.06\end{array}$ & $\begin{array}{r}-13 \\
-19.8 \\
13.2\end{array}$ \\
\hline NEM & $\begin{array}{l}\text { Model basin } \\
\text { AS } \\
\text { BoB }\end{array}$ & $\begin{array}{l}1.53 \\
1.29 \\
0.23\end{array}$ & $\begin{array}{l}1.3 \\
1.01 \\
0.29\end{array}$ & $\begin{array}{l}-15 \\
-21.7 \\
20.8\end{array}$ \\
\hline SIM & $\begin{array}{l}\text { Model basin } \\
\text { AS } \\
\text { BoB }\end{array}$ & $\begin{array}{l}0.128 \\
0.094 \\
0.034\end{array}$ & $\begin{array}{l}0.124 \\
0.083 \\
0.041\end{array}$ & $\begin{array}{r}-3.1 \\
-11.7 \\
20.6\end{array}$ \\
\hline SWM & $\begin{array}{l}\text { Model basin } \\
\text { AS } \\
\text { BoB }\end{array}$ & $\begin{array}{l}0.602 \\
0.489 \\
0.113\end{array}$ & $\begin{array}{l}0.522 \\
0.396 \\
0.127\end{array}$ & $\begin{array}{l}-13.3 \\
-19 \\
12.4\end{array}$ \\
\hline FIM & $\begin{array}{l}\text { Model basin } \\
\text { AS } \\
\text { BoB }\end{array}$ & $\begin{array}{l}0.141 \\
0.105 \\
0.036\end{array}$ & $\begin{array}{l}0.111 \\
0.073 \\
0.038\end{array}$ & $\begin{array}{r}-21.3 \\
-30.5 \\
5.6\end{array}$ \\
\hline
\end{tabular}

by biological processes; the remaining DIC is large enough to cause outgassing. The large values of outgassing in this region in both the cases is in no small measure due to significant increase in the mass transfer coefficient at the air-sea interface, which depends approximately quadratically on wind speed, by strong winds in the SWM Season. Moderate upwelling off the African coast (south of $\sim 8^{\circ} \mathrm{N}$ ), the west Indian coast and the east Indian coast has a similar but smaller effect. As the stratification in most of the $\mathrm{BoB}$ restricts the scope for vertical transport processes, the decrease in DIC and ALK due to biological processes is small and together they marginally increase surface $\mathrm{pCO}_{2}$ and outgassing. In other seasons, both the biological effects, both positive and negative, are much weaker in these regions.

Table 3 gives the annual and seasonal sea-toair carbon fluxes in the $\mathrm{AS}\left(<78^{\circ} \mathrm{E}, 0-27^{\circ} \mathrm{N}\right)$ and the $\mathrm{BoB}\left(>78^{\circ} \mathrm{E}, 0-27^{\circ} \mathrm{N}\right)$ in the standard and the abiotic runs. The biological processes decrease outgassing in the north Indian Ocean annually by $13 \%$. They also decrease outgassing in all the seasons, the largest decrease being in the FIM season (21 and $15 \%)$. The biological processes decrease outgassing in the AS annually by $20 \%$, and increase in the BoB by $13 \%$, but in absolute terms the latter effect is much smaller. The decrease in outgassing in the AS occurs in all seasons, the largest $(-30 \%)$ being in the FIM season. The biological processes 
increase outgassing in $\mathrm{BoB}$ in all seasons, the largest increase $(21 \%)$ being in the NEM season. This rather unexpected effect is due to the dominance of regeneration over carbon fixation in large parts of the $\mathrm{BoB}$ due to stratification effects.

\section{Concluding remarks}

We have presented results of the standard run of a model synthesized from physical oceanographic model (MOM2.2), marine ecosystem model of Fasham et al (1990) and carbon chemical model of Peng et al (1987) and Drange (1994). It is shown to capture qualitatively the trends of JGOFS, BoBPS and WOCE I1 observations in the north Indian Ocean. Since dust depositional models show sharp meridional southward drop south of the equator in dust deposition rates (Jickells et al 2005) and field observations of dissolved iron in the World Ocean show that dissolved iron concentrations in the north Indian Ocean amongst the highest (Moore and Braucher 2007; figure 2), it is reasonable to assume that iron limitation is not a serious issue above the equator. The quantitative discrepancies prima facie appear to be largely due to forcing errors in the physical model. The fact that incorrect physics is a major hurdle for accurate simulation of ecological and biogeochemical processes in the ocean is nicely demonstrated by Friedrichs et al (2006).

If we quantify the zonal contrast between the $\mathrm{BoB}\left(>78^{\circ} \mathrm{E},>0^{\circ} \mathrm{N}\right)$ and the $\mathrm{AS}\left(<78^{\circ} \mathrm{E},>0^{\circ} \mathrm{N}\right)$ as the difference between zonal averages of an oceanic variable at a given latitude, our model shows that the surface waters of the AS are, on an annual average, cooler, more saline, more alkaline and they have more dissolved inorganic carbon than the $\mathrm{BoB}$ (figure 8). The zonal contrast is muted in the equatorial region where the Wyrtki jet and the equatorial undercurrent provide mechanisms for reducing the zonal contrast. However, it increases with latitude north of $\sim 5^{\circ} \mathrm{N}$. Also, the zonal contrast persists in all seasons. Using a different measure of zonal contrast, Goyet et al (1999) observed that the zonal contrast between the AS and BoB in WOCE I1 (29 August-15 October 1995) data on $9 / 10^{\circ} \mathrm{N}$ transect is larger than what is observed over comparable distances in other oceans. The zonal contrast in these physical and chemical oceanic variables translates into the zonal contrast in $\mathrm{pCO}_{2}$ and the sea-to-air carbon flux.

We have conducted a gedanken computational experiment, called the abiotic run, in which the biological processes have been turned off in the north Indian Ocean during the simulation without altering the surface forcing or the initial conditions of physical and chemical variables. The difference between the results of the standard run and the abiotic run is interpreted as the effect of the biological processes on the seasonal variability of sea-to-air flux. This modelling exercise is intended to give insight into the role of biological processes on the seasonal time scale. The biological processes tend to decrease surface $\mathrm{pCO}_{2}$ in the northwest $\mathrm{AS}$ in all seasons (figure 11), and on a smaller scale near the west Indian coast, especially in FIM and NEM Seasons. High winds in the Findlater Jet region amplify the biological effect on the sea-toair carbon flux in a spectacular fashion resulting in a marked decrease in the outgassing (sea-to-air carbon flux) in the northwest AS in the SWM season (figure 12).

\section{Acknowledgements}

This work was carried out as a part of ocean modelling activities at C-MMACS sponsored by the Department of Ocean Development (DOD) under several projects. The authors thank DOD for their financial support. The authors thank Dr. Madhuprathap, Dr. Prasannakumar, Dr. Ramaiah and Dr. Sugandha, Scientists of National Institute of Oceanography for useful discussions and for providing the cruise data collected in Bay of Bengal under Bay of Bengal Process Studies programme. The authors thank Dr. Richard Barber, Dr. John Marra and Dr. Lou Codispoti for providing the access to U.S.JGOFS cruise data on U.S.JGOFS home page. The authors acknowledge the use of SeaWiFS data available on SeaWiFS home page in accord with the Research Users Terms and Conditions Agreement. The authors also thank Mr. R P Thangavelu, Scientist, C-MMACS for computer support. The authors wish to thank the referees for their suggestions.

\section{Appendix I}

\section{Equations of the biological and chemical models}

The biological model has seven ecosystem conservation equations of Phytoplankton $P$, Zooplankton $Z$, Bacteria $B$, Nitrate $N_{n}$, Ammonium $N_{r}$, Dissolved Organic Nitrogen $N_{d}$ and detritus $N_{p}$. These conservation equations have advective and diffusive terms of the same form as in the temperature and salinity. Their source-minus-sink terms (SMS) are given below.

$$
\begin{aligned}
\operatorname{SMS}(P)= & \left(1-\gamma_{1}\right) \bar{J}(z, t)\left[Q_{1}\left(N_{n}, N_{r}\right)+Q_{2}\left(N_{r}\right)\right] P \\
& -\mu_{1} P-G_{1}, \quad(\text { A1 })
\end{aligned}
$$




$$
\begin{aligned}
\operatorname{SMS}(Z)= & \gamma_{2}\left(G_{1}+G_{2}+G_{3}\right)-\left(\mu_{2}+\mu_{5}\right) Z \\
\operatorname{SMS}(B)= & U_{1}+U_{2}-G_{2}-\mu_{3} B \\
\operatorname{SMS}\left(N_{n}\right)= & -\bar{J}(z, t) Q_{1}\left(N_{n}, N_{r}\right) P \\
\operatorname{SMS}\left(N_{r}\right)= & {\left[\gamma_{3} \mu_{2}+\left(1-\gamma_{4}\right) \mu_{5}\right] Z+\mu_{3} B } \\
& -J(z, t) Q_{2}\left(N_{r}\right) P-U_{2}
\end{aligned}
$$

$$
\begin{aligned}
\operatorname{SMS}\left(N_{d}\right)= & \gamma_{1} \bar{J}(z, t)\left(Q_{1}\left(N_{n}, N_{r}\right)+Q_{2}\left(N_{r}\right)\right) P \\
& +\left(1-\gamma_{3}\right) \mu_{2} Z+\mu_{4} N_{p}-U_{1}, \quad(\mathrm{~A} 6)
\end{aligned}
$$

$$
\begin{aligned}
\operatorname{SMS}\left(N_{p}\right)= & \mu_{1} P+\left(1-\gamma_{2}\right)\left(G_{1}+G_{2}+G_{3}\right) \\
& -G_{3}-\mu_{4} N_{p}-\omega_{s} \partial N_{p} / \partial z .
\end{aligned}
$$

Note that predation $\gamma_{4} \mu_{5} Z$ is instantly exported to the bottom of the euphotic layer.

\section{Light limitation model of phytoplankton} growth (Fasham et al 1990)

$I(z, t)=I(0, t) \exp \left(k_{w} z-\int_{z}^{0} k_{c} P d z\right) P A R$

$$
V_{p}=a b^{c T}
$$

$$
J(z, t)=\frac{V_{p} \alpha I(z, t)}{\left[V_{p}^{2}+(\alpha I(z, t))^{2}\right]^{0.5}},
$$

$$
\bar{J}(z, t)=\frac{1}{z_{k}-z_{k+1}} \int_{z_{k+1}}^{z_{k}} J(z, t) d z .
$$

\section{Nitrogen uptake kinetics}

Nitrogen uptake kinetics is modelled by YS parameterization scheme, which is explained in section 2.2 (Yajnik and Sharada 2003; Sharada et al 2005).

$$
\begin{aligned}
Q_{1}\left(N_{n}, N_{r}\right) & =\frac{N_{n}}{k_{1}+N_{n}} \frac{1+a_{1} N_{r}}{1+b_{1} N_{r}}, \\
Q_{2}\left(N_{r}\right) & =\frac{N_{r}}{k_{2}+N_{r}} .
\end{aligned}
$$

Grazing functions (Fasham et al 1990)

$$
F=p_{1} P+p_{2} B+p_{3} D
$$

$$
G_{1}=\frac{g p_{1} P^{2} Z}{k_{3} F+p_{1} P^{2}+p_{2} B^{2}+p_{3} N_{p}^{2}},
$$

$$
G_{2}=\frac{g p_{2} B^{2} Z}{k_{3} F+p_{1} P^{2}+p_{2} B^{2}+p_{3} N_{p}^{2}},
$$

$$
G_{3}=\frac{g p_{3} N_{p}^{2} Z}{k_{3} F+p_{1} P^{2}+p_{2} B^{2}+p_{3} N_{p}^{2}} .
$$

\section{Bacterial growth (Fasham et al 1998)}

$$
\begin{aligned}
S & =\min \left(N_{r}, \eta N_{d}\right), \\
U_{1} & =\frac{V_{b} N_{d} B}{k_{4}+S+N_{d}}, \\
U_{2} & =\frac{V_{b} S B}{k_{4}+S+N_{d}} .
\end{aligned}
$$

\section{Chemical model (Drange 1994)}

The chemical model uses the two conservation equations for Dissolved Inorganic Carbon (DIC) and Alkalinity (ALK). They are essentially the same as Drange, except for modifications mentioned in section 2.3.

$$
\begin{aligned}
\mathrm{SMS}(\mathrm{DIC})= & -\bar{J}(z, t)\left[Q_{1}\left(N_{n}, N_{r}\right)+Q_{2}\left(N_{r}\right)\right] P R_{p} \\
& -\frac{\partial}{\partial t}\left(\mathrm{CaCO}_{3}\right)+\mu_{3} B R_{b} \\
& +\left[\gamma_{3} \mu_{2}+\left(1-\gamma_{4}\right) \mu_{5}\right] Z R_{p}, \quad(\mathrm{~A} 21) \\
\operatorname{SMS}(\mathrm{ALK})= & \bar{J}(z, t)\left[Q_{1}\left(N_{n}, N_{r}\right)-Q_{2}\left(N_{r}\right)\right] P \\
& -2 \frac{\partial}{\partial t}\left(\mathrm{CaCO}_{3}\right)+\mu_{3} B \\
& +\left[\gamma_{3} \mu_{2}+\left(1-\gamma_{4}\right) \mu_{5}\right] Z-U_{2} . \quad(\mathrm{A} 22)
\end{aligned}
$$


Appendix II

Biological model parameters in Experiments A, B, C and D

\begin{tabular}{|c|c|c|c|c|}
\hline & Phytoplankton parameters & & & \\
\hline$\alpha$ & Initial slope of P-I Curve & 0.025 & $\mathrm{~d}^{-1} /\left(\mathrm{Wm}^{-2}\right)$ & \\
\hline PAR & Photosynthetically active radiation & 0.4 & & \\
\hline$k_{c}$ & Light attenuation by $\mathrm{P}$ & 0.03 & $\mathrm{~m}^{-1}\left(\mathrm{mmolN} / \mathrm{m}^{3}\right)^{-1}$ & \\
\hline$k_{w}$ & Light attenuation due to water & 0.04 & $\mathrm{~m}^{-1}$ & \\
\hline $\begin{array}{l}\mathrm{a} \\
\mathrm{b} \\
\mathrm{c}\end{array}$ & Maximum growth rate parameters & $\begin{array}{l}0.6 \\
1.066 \\
1.0\end{array}$ & $\begin{array}{l}\mathrm{d}^{-1} \\
{ }^{\circ} \mathrm{C}^{-1}\end{array}$ & \\
\hline$\gamma_{1}$ & Exudation fraction & 0.05 & & \\
\hline$\mu_{1}$ & Specific mortality rate & 0.04 & $d^{-1}$ & \\
\hline$k_{1}$ & Half-saturation for nitrate uptake & 1.47 & $\operatorname{mmolN~} \mathrm{m}^{-3}$ & \\
\hline$k_{2}$ & Half-saturation for Ammonium uptake & 0.47 & mmolN m ${ }^{-3}$ & \\
\hline $\begin{array}{l}a_{1} \\
b_{1}\end{array}$ & Ammonium inhibition parameters & $\begin{array}{l}1.0 \\
3.0\end{array}$ & $(\operatorname{mmolN})^{-1}$ & \\
\hline \multirow[t]{2}{*}{$\mathrm{R}_{p}$} & Redfield ratio for $\mathrm{P}$ and $\mathrm{Z}$ & 7.0 & & \\
\hline & Zooplankton parameters & & & \\
\hline g & Maximum growth rate & $\begin{array}{l}1.0 \\
0.6\end{array}$ & $\begin{array}{l}d^{-1} \\
d^{-1}\end{array}$ & $\begin{array}{l}\operatorname{Exp} A, C, D \\
\operatorname{Exp} B\end{array}$ \\
\hline$\gamma_{2}$ & Assimilation efficiency & 0.75 & & \\
\hline $\mathrm{p}_{1}$ & Relative preference of $\mathrm{Z}$ for $\mathrm{P}$ & 0.4 & & \\
\hline $\mathrm{p}_{2}$ & Relative preference of $\mathrm{Z}$ for $\mathrm{B}$ & 0.3 & & \\
\hline $\mathrm{p}_{3}$ & Relative preference of $\mathrm{Z}$ for $\mathrm{N}_{\mathrm{p}}$ & 0.3 & & \\
\hline $\mathrm{k}_{3}$ & Half-saturation rate for ingestion & $\begin{array}{l}1.0 \\
0.6\end{array}$ & $\begin{array}{l}\text { mmolN } \mathrm{m}^{-3} \\
\mathrm{mmolN} \mathrm{m}^{-3}\end{array}$ & $\begin{array}{l}\operatorname{Exp} A, C, D \\
\operatorname{Exp} B\end{array}$ \\
\hline$\mu_{2}$ & Specific excretion rate & 0.1 & $\mathrm{~d}^{-1}$ & \\
\hline$\mu_{5}$ & Specific mortality rate & $\begin{array}{l}0.05 \\
0.1\end{array}$ & $\begin{array}{l}d^{-1} \\
d^{-1}\end{array}$ & $\begin{array}{l}\operatorname{Exp} A, B, C \\
\operatorname{Exp} D\end{array}$ \\
\hline$\gamma_{3}$ & Ammonium fraction of $\mathrm{Z}$ excretion & 0.75 & & \\
\hline$\gamma_{4}$ & Detrital fraction of $\mathrm{Z}$ mortality & $\begin{array}{l}0.33 \\
0.5\end{array}$ & & $\begin{array}{l}\operatorname{Exp} A, B \\
\operatorname{Exp} C, D\end{array}$ \\
\hline
\end{tabular}




\begin{tabular}{l|l|l|l|}
\hline & Bacterial parameters & & \\
\hline$V_{b}$ & Maximum growth rate & 2.0 & $\mathrm{~d}^{-1}$ \\
\hline$\mu_{3}$ & Specific excretion rate & 0.05 & $\mathrm{~d}^{-1}$ \\
\hline $\mathrm{k}_{4}$ & Half-saturation rate for uptake & 0.5 & $\mathrm{mmolN} \mathrm{m}^{-3}$ \\
\hline$\eta$ & Ammonium/DON uptake ratio & 0.6 & \\
\hline$\mu_{4}$ & Betrital parameters & & \\
\hline$\omega_{s}$ & Sinking velocity & 0.05 & $\mathrm{~d}^{-1}$ \\
\hline $\mathrm{R}_{B}$ & Redfield ratio for B & -4.0 & $\mathrm{~m} \mathrm{~d}^{-1}$ \\
\hline
\end{tabular}

Note: The values are common to all experiments, unless otherwise specified.

\section{References}

Anderson T R and Pondaven P 2003 Non-redfield carbon and nitrogen cycling in the Sargasso Sea: pelgic imbalances and export flux; Deep-Sea Res. I 50 573-591.

Anderson T R and Williams P J le B 1998 Modelling the Seasonal Cycle of Dissolved Organic Carbon at Station E1 in the English Channel; Estuarine, Coast. Shelf. Sci. 46 93-109.

Bates N R, Pequignet A C and Sabine C L 2006a Ocean carbon cycling in the Indian Ocean: 1. Spatiotemporal variability of inorganic carbon and air-sea $\mathrm{CO}_{2}$ gas exchange; Global Biogeochemical Cycles 20 GB3020, doi:10.1029/2005GB002491.

Bates N R, Pequignet A C and Sabine C L 2006b Ocean carbon cycling in the Indian Ocean: 2. Estimates of net community production; Global Biogeochemical Cycles 20 GB3021, doi:10.1029/2005GB002492.

Blackford J C and Burkill P H 2002 Planktonic community structure and carbon cycling in the Arabian Sea as a result of monsoonal forcing: the application of a generic model; J. Marine Sys. 36 239-267.

Dortch Q 1990 The Interaction between Ammonium and Nitrate Uptake in Phytoplankton; Mar. Ecol. Prog. Ser. 61 183-201.

Drange H 1994 An isopycnic coordinate carbon cycle model for the North Atlantic; and the possibility of disposing of fossil fuel $\mathrm{CO}_{2}$ in the ocean, $\mathrm{PhD}$ Thesis, The Nansen Environmental and Remote Sensing Center and Dept. of Mathematics, University of Bergen, Bergen, Norway.

Drange H 1996 A 3-dimensional isopycnic coordinate model of the seasonal cycling of carbon and nitrogen in the Atlantic Ocean; Phys. Chem. Earth 21(5-6) 503-509.

Esbensen S K and Kushnir Y 1981 The heat budget of the global ocean: An atlas based on estimates from the surface marine observations; Climatic Research Institute Report \#29, Oregon State University, Corvalis, OR, USA.

Fasham M J R, Ducklow H W and McKelvie S M 1990 A Nitrogen-based Model of Plankton Dynamics in the Oceanic Mixed Layer; J. Mar. Res. 48 591-639.

Friedrichs M A M, Hood R R and Wiggert J D 2006 Ecosystem model complexity versus physical forcing: Quantifi- cation of their relative impact with assimilated Arabian Sea data; Deep-Sea Res. II 53 576-600.

Gopalkrishna V V, Murthy V S N, Sengupta D, Shenoy S and Araligidad N 2002 Upper ocean stratification and circulation in the northern Bay of Bengal during southwest monsoon of 1991; Cont. Shelf Res. 22 791-802.

Goyet C, Coatanoan C, Eischeid G, Amaoka T, Okuda K, Healy R and Tsunogai S 1999 Spatial variation of total $\mathrm{CO}_{2}$ and total alkalinity in the northern Indian Ocean: A novel approach for the quantification of anthropogenic $\mathrm{CO}_{2}$ in seawater; J. Mar. Res. 57 135-163.

Hastenrath S, Lamb P and Greischar L 1989 Climatic Atlas of the Indian Ocean (Madison: University of Wisconsin Press).

Hellerman S and Rosenstein M 1983 Normal monthly wind stress over the world ocean with error estimates; J. Phys. Oceanogr. 13 1093-1104.

Jickells $\mathrm{T}$ D, An Z S, Andersen $\mathrm{K}$ K, Baker A R, Bergametti G, Brooks N, Cao J J, Boyd P W, Duce R A, Hunter K A, Kawahata H, Kubilay N, laRoche J, Liss P S, Mahowald N, Prospero J M, Ridgwell A J, Tegen I and Torres R 2005 Global iron connections between desert dust, ocean biogeochemistry and climate; Science 308 $67-71$.

Levitus S, Boyer T P and Antonov J 1994 World Ocean Atlas; Vol. 4, NESDIS, Washington.

Leonard B P 1979 A stable and accurate convective modelling procedure based on quadratic upstream interpolation; Computer Methods in Applied Mechanics and Engineering 19 59-98.

Madhupratap M, Gauns M, Ramaiah N, Prasanna Kumar S, Muraleedharan P M, de Souza S N, Saradesai S and Muraleedharan U 2003 Biogeochemistry of the Bay of Bengal: Physical, Chemical and Primary Productivity characteristics of the central and western Bay of Bengal during Summer Monsoon 2001; Deep-Sea Res. II 50 881-896.

Martin J H 1990 Glacial-interglacial $\mathrm{CO}_{2}$ change: The iron hypothesis; Paleoceanography 5 1-13.

McCarthy J J, Garside C and Nevins J L 1999 Nitrogen dynamics during the Arabian Sea northeast monsoon; Deep-Sea Res. Part II 46(8-9) 1623-1664.

Moore J K and Braucher O 2007 Observations of dissolved iron concentrations in the World Ocean: implication and 
constraints for ocean biogeochemical models; Biogeosciences Discussions 4 1241-1277.

Moore J K, Doney S C, Kleypas J C, Glover D M and Fung I Y 2002a An intermediate complexity marine ecosystem model for the global domain; Deep-Sea Res. II 49 403-462.

Moore J K, Doney S C, Glover D M and Fung I Y 2002b Iron cycling and nutrient limitation patterns in surface waters of the world ocean; Deep-Sea Res. II 49 $463-508$

Myrmehl C and Drange H 1998 Distribution of total alkalinity, total dissolved inorganic carbon and derived parameters in the world oceans; Unpublished Manuscript.

Oberhuber J M 1988 An atlas based on the COADS data set: The budgets of heat, buoyancy and turbulent kinetic energy at the surface of the ocean; Tech. Rep. 15, MaxPlanck Institute for Meteorologie, Hamburg. Digital data available at http://ingrid.ldgo.columbia.edu.

Pacanowski R C and Philander G 1981 Parametrization of vertical mixing in numerical models of the tropical ocean; J. Phys. Oceanogr. 11 1442-1451.

Pacanowski R C 1995 MOM2 Documentation, User's Guide and Reference Manual. Ver 1.0, GFDL Ocean Tech. Report, No. 3.

Paulson C A and Simpson J J 1977 Irradiance measurements in the upper ocean; J. Phys. Oceanogr. 7 952-956.

Peng T H, Takahashi T, Broecker W S and Olafsson J 1987 Seasonal variability of carbon dioxide, nutrients and oxygen in the Northern Atlantic surface water: observations and a model; Tellus 39B 439-457.

Prasanna Kumar S, Muraleedharan P M, Prasad T G, Gauns M, Ramaiah N, de Souza S N, Sardesai S and Madhupratap M 2002 Why is the Bay of Bengal less productive during summer monsoon compared to the Arabian Sea?; Geophys. Res. Lett. 29(24) 2235.

Prasanna Kumar S, Nuncio M, Narvekar J, Kumar A, Sardesai S, de Souza S N, Gauns M, Ramaiah N and Madhuprathap M 2004 Are eddies nature's trigger to enhance biological productivity in the Bay of Bengal?; Geophys. Res. Lett. 31 L07309, doi:10.1029/2003 GL019274.

Sabine C L, Wanninkhof R, Key R M, Goyet C and Millero F J 2000 Seasonal $\mathrm{CO}_{2}$ fluxes in the tropical and subtropical Indian Ocean; Marine Chemistry 72 33-53.

Sarma V V S S 2003 Monthly variability in surface $\mathrm{pCO}_{2}$ and net air-sea $\mathrm{CO}_{2}$ flux in the Arabian Sea; J. Geophys. Res. 108(C8) 3255, doi:10.1029/2001JC001062.

Sarma V V S S, Swathi P S, Dileep Kumar M, Prasannakumar S, Bhattathiri P M A, Madhupratap M, Ramaswamy V, Sarin M M, Gauns M, Ramaiah N, Sardessai S and de Souza S N 2003 Carbon budget in the eastern and central Arabian Sea: An Indian JGOFS synthesis; Global Biogeochemical Cycles 17(4) 1102, doi:10.1029/2002GB001978.

Sarmiento J L, Slater R D, Fasham M J R, Ducklow H W, Togglweiler J R and Evans G T 1993 A seasonal three-dimensional ecosystem model of nitrogen cycling in the north Atlantic euphotic zone; Global Biogeochemical Cycles 7(2) 417-450.

Sarmiento J L, Monfray P, Maier-Reimer E, Aumont O, Murnane R J and Orr J C 2000 Sea-air $\mathrm{CO}_{2}$ fluxes and carbon transport: A comparison of three ocean general circulation models; Global Biogeochemical Cycles 14(4) $1267-1281$.

Schott F A and McCreary J P 2001 The monsoon circulation of the Indian Ocean; Progr. Oceanogr. 51 1-123.

Shankar D, Vinayachandran P N and Unnikrishnan A 2002 The monsoon currents in the north Indian Ocean; Progr. Oceanogr. 52 63-120.

Sharada M K and Yajnik K S 1997 Seasonal variation of chlorophyll and primary productivity in the Central Arabian Sea: A macrocalibrated upper ocean ecosystem model; Proc. Indian Acad. Sci. (Earth Planet. Sci.) 106 $33-42$.

Sharada M K, Yajnik K S and Swathi P S 2005 Evaluation of six relations of the kinetics of uptake by phytoplankton in multi-nutrient environment using JGOFS experimental results; Deep-Sea Res. II 14-15 1845-2078.

Shenoi S C, Shankar D, Gopalkrishna V V and Durand F 2005 Role of ocean in the genesis and annihilation of the core of the warm pool in the southeastern Arabian Sea; Mausam 56(1) 147-160.

Smith S, Roman M, Prusova I, Wishner K, Gowing M, Codispoti L A, Barber R, Marra J and Flagg C 1998 Seasonal response of zooplankton to monsoonal reversals in the Arabian Sea; Deep-Sea Res. II 45 2369-2403.

Swathi P S, Sharada M K and Yajnik K S 2000 A coupled physical-biological-chemical model for the Indian Ocean; Proc. Indian Acad. Sci. (Earth Planet. Sci.) 109(4) 503-537.

Takahashi T, Wanninkhoff R, Feely $\mathrm{R}$ A, Weiss $\mathrm{R}$ F, Chipman D W, Bates N, Olafsson J, Sabine C and Sutherland S C 1999 Net air-sea $\mathrm{CO}_{2}$ flux over global oceans: an improved estimate based on sea-air $\mathrm{pCO}_{2}$ difference; In: Proceedings of $2^{\text {nd }}$ International Symposium on $\mathrm{CO}_{2}$ in the oceans (ed.) Nojiri Y; Centre for Global environmental Research, National Institute for Environmental Studies, Tsukuba, Japan, pp. 9-14.

Vinaychandran P N, Murthy V S N and Babu V R 2002 Observations of barrier layer formation in the Bay of Bengal during summer monsoon; J. Geophys. Res. 107 19 1-19.

Vinaychandran P N, Chauhan P, Mohan M and Nayak S 2004 Biological response of the sea around Sri Lanka to summer monsoon; Geophys. Res. Lett. 30 L01302.

Wanninkhof R 1992 Relationship between wind speed and gas exchange over the ocean; J. Geophys. Res. 97(C5) 7373-7381.

Wiggert J D, Hood R R, Banse K and Kindle J C 2005 Monsoon-driven biogeochemical processes in the Arabian Sea; Prog. Oceanogr. 65 176-213.

Wiggert J D, Murtugudde R G and Christian J R 2006 Annual ecosystem variability in the tropical Indian Ocean: Results of a coupled bio-physical ocean general circulation model; Deep-Sea Res. II 53 644-676.

Wroblewski J S 1977 A model of phytoplankton plume formation during variable Oregon upwelling; J. Mar. Res. 35 357-394.

Yajnik K S and Sharada M K 2003 Ammonium Inhibition of Nitrate Uptake by Phytoplankton: A New Relation Based on Similarity and Hyperbolicity; Curr. Sci. 85(8) 1180-1189. 